\title{
Discussion Paper No. 18-013 \\ Trust-Based Work Time and the Productivity Effects of Mobile Information Technologies in the Workplace
}

Steffen Viete and Daniel Erdsiek

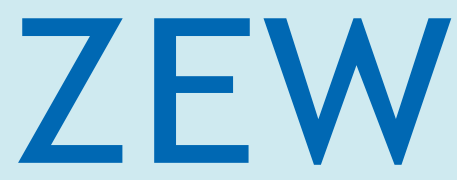

Zentrum für Europäische Wirtschaftsforschung $\mathrm{GmbH}$

Centre for European

Economic Research 


\title{
Discussion Paper No. 18-013 \\ Trust-Based Work Time and the Productivity Effects of Mobile Information Technologies in the Workplace
}

\author{
Steffen Viete and Daniel Erdsiek
}

Download this ZEW Discussion Paper from our ftp server:

http://ftp.zew.de/pub/zew-docs/dp/dp18013.pdf

Die Discussion Papers dienen einer möglichst schnellen Verbreitung von neueren Forschungsarbeiten des ZEW. Die Beiträge liegen in alleiniger Verantwortung der Autoren und stellen nicht notwendigerweise die Meinung des ZEW dar.

Discussion Papers are intended to make results of ZEW research promptly available to other economists in order to encourage discussion and suggestions for revisions. The authors are solely responsible for the contents which do not necessarily represent the opinion of the ZEW. 


\title{
Trust-Based Work Time and the Productivity Effects of Mobile Information Technologies in the Workplace
}

\author{
Steffen Viete* and Daniel Erdsiek ${ }^{\ddagger}$
}

\author{
March 2018
}

\begin{abstract}
We investigate whether the returns to mobile information and communication technology (ICT) in the workplace are contingent on granting employees autonomy over the structure of their workday through trust-based work time arrangements (TBW). Our regression analysis is based on a production function framework and exploits fine-grained firm survey data on ICT use and organisational practices for 1,045 service firms in Germany. We find empirical support for the argument that the returns to mobile ICT are higher when TBW allows for discretion over when, where and how to perform work-related tasks. The finding holds when we account for more limited forms of workplace flexibility, suggesting that the high degree of formal employee autonomy under TBW drives the complementarity between mobile ICT and organisational practices.
\end{abstract}

JEL-Classification: D22, L22, M10, O33.

Keywords: mobile information and communication technologies, ICT, trust-based work time, work organisation, complementarity, productivity, firm performance.

* Centre for European Economic Research (ZEW) Mannheim, P.O. Box 103443, 68034 Mannheim, email: viete@zew.de. For further information on the author' projects see www.zew.de/staff_sve.

$\ddagger$ Centre for European Economic Research (ZEW) Mannheim, P.O. Box 103443, 68034 Mannheim, email: erdsiek@zew.de. For further information on the author's projects see www.zew.de/staff_der. We would like to thank Daniel Arnold, Melanie Arntz, Irene Bertschek, Benjamin Engelstätter, Horst Entorf, Chris Forman, Christina Gathmann, Michael Kummer, Thomas Niebel, Fabienne Rasel, Patrick Schulte, Susanne Steffes, as well as participants of ZEW internal seminars, DRUID 2016, EALE 2016, EARIE 2016 and the 3rd Workshop on Ubiquitous Working for their valuable comments. This paper was written as part of the project "Challenges and Opportunities Arising from Ubiquitous Working" funded by the Leibniz Association. An earlier version of this paper is available as ZEW Discussion Paper 15-087 titled "Mobile Information and Communication Technologies, Flexible Work Organization and Labor Productivity: Firm-Level Evidence". All remaining errors are our own. 


\section{Introduction}

Developments in information and communication technology (ICT) have been a main driver of changes in the workplace in recent decades and the successful adoption of digital technologies is deemed to be crucial for firms' competitiveness. One of the key technological innovations in the workplace in recent years has been the diffusion of mobile ICT with an internet connection, such as notebooks, tablets and smartphones. The expansion of mobile ICT marks the next step in the decentralisation of computing technologies following the development of the personal computer, which relocated computing power from mainframe computers to workers' desktops in the 1980s, and the diffusion of the internet in the 1990s (Hitt and Brynjolfsson, 1997). In Germany, for instance, the diffusion of these two classical forms of ICT in the workplace has by now almost stagnated, as measured by the share of employees working predominantly at a personal computer or having access to the internet (Figure 1). In contrast, the share of employees who have been equipped with mobile ICT devices by their employer has nearly doubled from $12 \%$ to $23 \%$ between 2010 and 2014. Firms' adoption of mobile ICT is driven by the dramatically declining prices of these technologies and improvements in the wireless infrastructure supporting mobile connectivity, i.e. access to internal documents and information as well as the ability to communicate with customers and business partners from virtually everywhere at any time.

« Figure 1 about here »

With digital communication and information processing becoming increasingly ubiquitous, mobile ICT is widely expected to change how work will be organised in the future, dissolving its temporal and spatial boundaries (e.g. Kossek and Michel, 2010). This expectation is in line with empirical findings at the individual level showing that employees exploit mobile ICT to exert more control over their working environment and gain increased flexibility in where, when and how they perform work-related tasks (e.g. Golden and Geisler, 2007; Hislop and Axtell, 2011; Mazmanian et al., 2013). The greater individual flexibility provided by mobile ICT suggests that firms can leverage these technologies when formal work arrangements accommodate complementary organisational decision rights. In this vein, descriptive firm-level evidence based on cross-country surveys shows that the use of mobile ICT for the purpose of working outside the employer's physical premises is often associated with increased working time autonomy (Eurofound and International Labour Office, 2017). The hypothesis that the diffusion of mobile ICT can lead to changes in the organisation of work is also justified by existing research on the effects of ICT on firm performance. A considerable body of evidence shows that firms must match distinct (information) technologies with adequate organisational practices in 
order to achieve higher productivity gains from technology adoption. In particular, this literature highlights organisational practices which emphasise employee autonomy and decentralised decision making to act as organisational complements to generic investments in ICT (e.g. Bresnahan et al., 2002). However, direct empirical evidence supporting the notion that mobile ICT can move organisational practices towards greater flexibility due to complementarity is still scarce.

In this study, we investigate the importance of mobile ICT for a firm's internal organisation by focusing on complementarity between the use of mobile ICT and flexible work arrangements. In particular, we study whether firms can achieve higher productivity gains from mobile ICT if it is matched by organisational practices which delegate appropriate decision rights over when, where and how to engage in work-related tasks. As mobile ICT has started to uncouple information access and processing from office space and standard working hours, harnessing their full potential might require that employees are provided with extensive control over the whole structure of the workday. Working arrangements granting this high degree of employee autonomy have become more and more common and are referred to as "trust-based work time" arrangements (TBW) (Godart et al., 2017). ${ }^{1}$ TBW differs from more traditional flexible working arrangements as it involves a transition from working time registration to the evaluation of employees by measurable objectives, i.e. a shift from input control to output control, thus reducing the emphasis on when and where work is completed (Beckmann and Hegedues, 2011; Singe and Croucher, 2003). Establishing a results-only work environment, TBW implies workplace flexibility along multiple dimensions and often gives employees the right to decide where they work, thus allowing them to work from home (Kelly et al., 2011; Moen et al., 2011).

In order to test whether employee autonomy granted by TBW is relevant for the efficient use of mobile ICT, we account for complementarities in a classical production function framework. For our regression analysis, we gathered unique survey data containing detailed information on the use of ICT and organisational practices in 1,045 German service firms. The data allow us to distinguish the degree of employee autonomy afforded by TBW from that from more limited forms of workplace flexibility. In addition, we conduct several sensitivity checks employing rich information on firm heterogeneity and instrumental variable estimation. As a country in which employee autonomy with regard to the structure of the workday has a long-standing tradition, Germany serves as a particularly relevant setting for our analysis. In the aftermath of the introduction of flextime arrangements in the 1960s (Avery and Zabel, 2001) and collective agreements in the metal industry in 1984, sector and plant agreements on the structure of working hours became

\footnotetext{
${ }^{1}$ Beckmann et al. (2017) discuss these work arrangements using the term "self-managed working time".
} 
common and have led to great variation in arrangements across firms (Berg et al., 2004). The importance of flexible work arrangements in Germany has also led TBW arrangements to become an increasingly common phenomenon since their emergence during the 1990s (Godart et al., 2017).

We contribute to the literature in several ways. To the best of our knowledge, our article is the first to empirically analyse complementarities between mobile ICT and firms' internal organisation. It thus contributes to the understanding of the implications of one of the recent technological changes in the workplace for organisational practices. In the same way, the analysis sheds light on the returns on investments in these technologies and in TBW as an organisational practice, respectively. We thereby provide a first step to integrating the aspect of workplace flexibility into the literature on ICT productivity. Furthermore, much of the prior work in the field has focused either on the manufacturing sector, or on narrow settings, such as health care (Hitt and Tambe, 2016; Litwin, 2011). In contrast, our study provides large-scale statistical evidence using data which is representative of a wide range of service industries. The analysis thus more aptly addresses the implications for knowledge-based work in increasingly service-oriented economies. Finally, we contribute to the increasing body of evidence, which expands the notion of complementarity between ICT as a homogenous technology and generic 'decentralised' work organisation. In this vein, our study contributes to a more precise view of how the advancement of specific technologies can raise the value of particular organisational practices.

\section{Background Discussion}

\subsection{ICT, employee autonomy and firm performance}

This study is related to the vast literature on the effects of ICT and modern management practices on firm performance and, more specifically, to the literature on complementarities between ICT and organisational practices. Moreover, our analysis is related to studies evaluating work-life balance practices and workplace flexibility.

ICT has long been a central aspect in research on firm performance as well as organisational change. Positive productivity effects of ICT as a general purpose technology are well-documented at the firm level and the individual level (e.g. Bertschek, 2012; Draca et al., 2007; Kretschmer, 2012). One of the main findings of ICT productivity research is that firms can differ considerably in their ability to realise the benefits of ICT investments. Over time, it was found that firms which benefit most from their ICT use are those who make complementary changes to their internal organisation and organisational decision 
rights (Brynjolfsson and Hitt, 2003). As mobile ICT has only started to diffuse quite recently, large-scale empirical evidence on their effects on firm performance is scarce. An exception is the study by Bertschek and Niebel (2013) who document a positive relation between mobile ICT and labour productivity for a sample of German manufacturing and service firms. Their analysis, however, abstracts from the potential interplay between this new technology, work organisation and firm performance.

In general, the diffusion of ICT has coincided with radical changes in work organisation moving away from traditional Tayloristic organisations to modern management practices emphasising the decentralisation of decision-making processes and supporting incentives. Bresnahan et al. (2002) provided early large-scale empirical evidence that firms' ICT investment and organisational structures emphasising employee autonomy mutual reinforce one another. Further studies have confirmed similar complementarities between ICT and working arrangements in different contexts (e.g. Bartel et al., 2007; Garicano and Heaton, 2010; Hitt and Tambe, 2016; Litwin, 2011). More recently, for instance, Bloom et al. (2012) show that the higher returns to ICT use of US-based firms compared to firms in Europe can be attributed to differences in the use of innovative people management practices.

In contrast to treating ICT as a homogeneous technology, more recent theoretical and empirical contributions have started to highlight that different types of ICT can have distinct implications for firm performance and organisation (e.g. Aral and Weill, 2007). Results from this literature suggest that mobile ICT as a specific technology might interact with firms' internal organisation differently from past waves of digitisation in the workplace. For example, Aral et al. (2012) show that, by allowing firms to more accurate monitor employee performance, human capital management software increases firm productivity when used in conjunction with performance pay and human resource analytics practices. Based on a theoretical model of the organisation as a knowledge-based hierarchy, Bloom et al. (2014) argue that information technologies and communication technologies can have opposing effects on the discretion of employees. On the one hand, better communication of knowledge shifts decisions to higher tiers of the hierarchy, thus fostering specialisation and centralisation. Cheaper access to information, on the other hand, has an empowering effect, which allows employees to solve problems and tasks without relying on others. Along these lines, mobile ICT might foster employee autonomy to such a degree that ubiquitous access to digitised information leads to reduced informational frictions. In this way, the potential costs of allowing employees to work autonomously under flexible work arrangements might be reduced by information technology which is uncoupled from standard workplaces and working hours. 
Even if mobile ICT and workplace flexibility practices are likely to be mutually reinforcing, their joint effect on firm performance is unclear a priori. From a theoretical perspective, this technology-enabled workplace flexibility might improve employees' effort and job performance for several reasons. First, due to the delegation of decision rights employees can use superior information to help them to complete their work-related tasks most efficiently (Lazear and Gibbs, 2015). They can use private information to allocate their working hours in accordance to life responsibilities or their individual circadian rhythm and work when their personal productivity is at its peak (Pierce and Newstrom, 1980; Shepard et al., 1996). Second, since job autonomy is an important determinant of self-motivation and work morale (Deci and Ryan, 1985), workplace flexibility might positively affect employees' performance through job enrichment (Beckmann et al., 2017). Third, worker effort might increase due to the reciprocal behaviour of employees who value workplace flexibility as a fringe benefit provided by their employer. ${ }^{2}$

However, technology-enabled workplace flexibility could also exhibit detrimental effects on productivity-related factors. In line with the effort-recovery model (Meijman and Mulder, 1998), a lack of cognitive distraction from work-related activities and the interruption of leisure time for work-related reasons outside regular working hours can provoke work-family conflicts (Boswell and Olson-Buchanan, 2007), reduce job satisfaction or even cause mental strain and other health-related problems (Askenazy and Caroli, 2010; Sonnentag, 2001). Furthermore, allowing employees to work at disparate locations and times involves principal-agent problems and might lead to higher coordination and monitoring costs from the firm's perspective (Alonso et al., 2008; Prendergast, 2002).

However, a growing number of empirical studies provide evidence for the positive effects of workplace flexibility in terms of TBW on individual effort (Beckmann et al., 2017), firm productivity (Beckmann, 2016) and firms' innovation success (Godart et al., 2017). Furthermore, Bloom et al. (2015) recently provided experimental evidence for the positive effects of spatial workplace flexibility in terms of working from home arrangements on job performance and work satisfaction. In spite of a growing economic literature focussing on workplace flexibility, this aspect has yet to be integrated into the ICT productivity literature.

\subsection{TBW and Flexible Work Arrangements in Germany}

Besides technological advancements, rising societal demand for greater workplace flexibility and the pursuit of competitive advantages have driven firms to adopt new methods of flexible organisation over recent decades (Council of Economic Advisors, 2010; Goldin,

\footnotetext{
${ }^{2}$ Social exchange theory (Homans, 1958) and gift exchange theory (Akerlof, 1982) describe this kind of reciprocal behaviour.
} 
2014). Today, firms looking to increase worker autonomy have a whole continuum of common working arrangements to choose from. These range from limited decision rights over when the workday starts and finishes, or the option to work from home occasionally, to extensive control over the entire structure of the workday. The working arrangement at the latter extreme, trust-based work time, has become increasingly significant over recent decades (Godart et al., 2017).

TBW implies workplace flexibility along multiple dimensions. As summarised by Kossek and Michel (2010), workplace flexibility practices can generally encompass employee autonomy over the dimensions of when to work, such as working time accounts, where to work, such as working from home arrangements, how much to work, and the continuity of work, such as long-term and short-term breaks. TBW is the only common working practice to date that can span all of these dimensions and is therefore typically considered the working arrangement which involves the highest degree of formal employee autonomy in Germany (e.g. Wingen, 2004). The abandonment of records of working times mitigates the employer's direct control over the employees' work effort. However, the evaluation of employees by their work product under TBW can also reduce monitoring costs (Beckmann et al., 2017) which would otherwise be high when employees effectively use mobile ICT to work outside regular workplaces and working hours.

TBW is not explicitly defined under German labour law. However, in order to comply with the law, the employer still has to assure that mandatory breaks and rest periods are taken and that overtime is documented. Under TBW, the responsibility for documenting overtime is usually delegated to the employee. Moreover, TBW is usually not part of the contractual arrangement between employer and employee but settled through a firm wide employment agreement. Due to the strong co-determination rights afforded to workers in Germany, the works council is usually involved in such an organisational change related to working hours and compensation. ${ }^{3}$

While the focus of our analysis lies on TBW as an organisational complement to mobile ICT, we need to differentiate TBW from more limited forms of temporal and spatial flexibility in our empirical analysis. In particular, with regard to temporal flexibility, we consider the use of working time accounts. They cover a variety of more specific arrangements which involve the accumulation of time credits/debits and differ in terms of how long employees have to balance their account. One of the most common forms are flextime arrangements, under which accounts must be balanced on a daily basis and which allow employees to vary their start and end time around certain core mandatory hours (Avery and Zabel, 2001). To date, they are still the most prominent flexible time arrangement in Germany and employees use them extensively to adjust their weekly working schedule or

\footnotetext{
${ }^{3}$ See also the discussion by Godart et al. (2017).
} 
take time off to take care of family and personal issues (Promberger, 2001; Seifert, 1993). Finally, we want to differentiate TBW from working arrangements which purely grant spatial flexibility by allowing employees to work off-site at multiple, disparate locations. To date, working from home arrangements are the dominating working arrangements granting flexibility regarding the place of work. Typical working from home arrangements allow employees to work part of their regular paid working hours from home, either occasionally or on a regular basis (Council of Economic Advisors, 2010). The number of individuals and jobs compatible with home-based work has been closely related to developments in ICT since employees working off-site are dependent on technology to interact with colleagues, engage in work-related tasks and deliver their work output.

\section{Methodology}

Complementarity between two economic activities $x_{1}$ and $x_{2}$, in our case the use of mobile ICT and TBW, implies that doing more of one activity increases the marginal benefit of doing the other. In principle, the literature has put forward two types of statistical tests for the existence of complementarities between economic activities (Athey and Stern, 1998; Brynjolfsson and Milgrom, 2013). Most commonly, studies test for complementarities indirectly, by looking at (controlled) correlations between input factors (factor demand equations). If two activities are complements and this is well understood by the firm, one should observe a clustering of adoption decisions. Thus a significant positive correlation is a necessary condition for complementarity (Holmstrom and Milgrom, 1994). A more direct test for complementarities focuses on analysing performance differences. This involves testing whether the hypothesised complements are more productive when adopted jointly rather than individually by estimating productivity equations. Formally, if the firms' production function $f\left(x_{1}, x_{2}\right)$ is smooth and twice continuously differentiable in the potential complements, $x_{1}$ and $x_{2}$, complementarity of the two variables is indicated by a positive cross-partial derivative of the production function: $\left(\partial^{2} f / \partial x_{1} \partial x_{2}\right)>0$ (Milgrom and Roberts, 1990).

Each of the two tests tends to have the highest statistical power when the other is weakest. If mobile ICT and TBW were actually complements, firms would seek to adopt them jointly. If managers are fully aware of a set of complements and have complete control over the individual factors, we would expect all firms to adopt the system of complements and correlation will be strong. A productivity test, on the contrary, would have little power to identify benefits from adopting the system of complements in this hypothetical situation, as firms would not adopt one complement in isolation. However, in a situation where firms are still experimenting with various practices or do not have 
full control over any of the complementary factors, correlation of complementary practices would not be perfect but there should be detectable differences in productivity (Aral et al., 2012; Brynjolfsson and Milgrom, 2013).

The latter case is likely more relevant to our application, especially due to the novelty of mobile ICT. As mobile ICT only recently started diffusing in the business sector and wireless internet infrastructure in Germany has matured only over recent years, firms' knowledge of how to make effective use of these new technologies is likely still limited. Jovanovic and Stolyarov (2000) and Bresnahan et al. (2002) show that complements might be upgraded at different times if their identification and implementation involves uncertainty and learning. In addition, we draw on the vast literature on organisational practices and complements, which assumes that organisational practices tend to persist over time and are hard to change in the case of incumbent firms, as justified by high adjustment costs of organisational change (Autor et al., 2002; Milgrom and Roberts, 1990; Tambe et al., 2012). Consequently, if organisational practices are quasi-fixed in the short run, managers were not able to act on them efficiently over the diffusion period of mobile ICT. While mobile ICT and relevant organisational complements might not be clustered under these circumstances, their joint impact on productivity will still be measurable. We therefore focus on analysing complementarities within a classical production function framework.

Economic theory views the production process of a firm as a function describing how the production inputs consumed by the firm can be transformed into output. In line with much of the literature, we conduct our productivity test for complementarity between mobile ICT and TBW within an augmented Cobb-Douglas production function framework, which postulates a simple functional relationship between the output a firm produces and the inputs it requires. This production function is most commonly used in the ICT productivity literature (Cardona et al., 2013), in studies on productivity returns to organisational practices and work arrangements (e.g. Beckmann et al., 2017; Black and Lynch, 2004; Shepard et al., 1996) and, in particular, in studies testing for complementarity between ICT and organisation (e.g. Bloom et al., 2012; Bresnahan et al., 2002; Tambe et al., 2012). It relates the output produced by firm $i, Y_{i}$, to the inputs labour, $L_{i}$, and physical capital, $K_{i}$, such that

$$
Y_{i}=A_{i} K_{i}^{\alpha_{K}} L_{i}^{\alpha_{L}}
$$

In addition, $A_{i}$ is a Hicks-neutral productivity term. This firm-specific efficiency is allowed to depend on the use of mobile ICT $\left(M I C T_{i}\right)$ as well as trust-based work $\left(T B W_{i}\right)$ :

$$
A_{i}=\exp \left(\alpha+\beta M I C T_{i}+\gamma T B W_{i}+\delta\left(M I C T_{i} * T B W_{i}\right)+\lambda^{\prime} \mathbf{x}_{i}+u_{i}\right)
$$


In this way, mobile ICT and TBW are allowed to shift the firms' production possibility frontier and make the use of other inputs, such as capital and labour, more productive. We furthermore have productivity depend on other observable factors, $\mathbf{x}_{i}$, such as firms' general ICT intensity and the employees' skill structure, as well as a stochastic residual, $u_{i}$.

Combining Equations (1) and (2) and taking logs, our primary model for the augmented Cobb-Douglas production function which we will estimate reads as

$$
\begin{aligned}
\ln \left(Y_{i}\right) & =\alpha+\alpha_{L} \ln \left(L_{i}\right)+\alpha_{K} \ln \left(K_{i}\right)+ \\
& +\beta M I C T_{i}+\gamma T B W_{i} \\
& +\delta\left(M I C T_{i} * T B W_{i}\right)+\lambda^{\prime} \mathbf{x}_{i}+u_{i} .
\end{aligned}
$$

Extended Cobb-Douglas production functions analogous to Equation (3) have been the workhorse model in the empirical literature on complementarities, as they constitute an approximation of more complex production functions (such as the translog) which is easy to interpret. The $\beta$ and $\gamma$ coefficients capture the main effects of mobile ICT and TBW. Our primary interest lies in the model parameter $\delta$ : A positive cross-partial derivative of the production function with respect to mobile ICT and TBW indicates that the two form a system of complements reinforcing each other and using TBW intensively increases the marginal return of using mobile ICT. Given our specification of the empirical production function, the test on the cross-partial derivative boils down to checking whether $\delta>0$ after controlling for other factors affecting the production process. We estimate our model by ordinary least squares (OLS) with heteroskedasticity-robust standard errors. After estimating Equation (3) as our baseline model, we will subsequently test the robustness of our main findings to common threats to identifying complements within a production function framework.

\section{Data and Variables}

\subsection{Data Set}

For our empirical analysis, we employ fine-grained survey data on the use of ICT, TBW and other flexible working practices in German service firms. The data originate from the firm-level ICT-Survey by the Centre for European Economic Research (ZEW) conducted via computer-assisted telephone interviews in $2014 / 2015 .{ }^{4}$ In the services sector, knowledge work is a considerable input share and workplace flexibility is more prevalent than in

\footnotetext{
${ }^{4}$ For detailed information on the data see Bertschek et al. (2017). For further information on data access see http://kooperationen.zew.de/en/zew-fdz/provided-data/zew-ict-survey.html.
} 
sectors requiring employees to work at a fixed workplace in order to perform their tasks, such as manufacturing (Eurofound and International Labour Office, 2017). Focusing our analysis on the services sector, furthermore reduces heterogeneity of production processes across the firms in our estimation sample.

After data cleaning and due to item-nonresponse we arrive at a final estimation sample of 1,045 observations. ${ }^{5}$ As the industry affiliation was manually verified during the survey process and is thus full observed, it can be used to assess the representativeness of the estimation sample. The distribution of the firms over industries in the full sample and the estimation sample is shown in Table A.1 in the appendix and suggests that the distribution over industries is about the same in both samples.

\subsection{Variables}

An overview of the key variables in our analysis is provided by Table A.2 in the appendix. In order to measure the firms' use of mobile ICT, we asked for the share of employees the firms equipped with mobile devices which provide wireless internet access, such as notebooks, smartphones or tablets (\% emp. mobile ICT).

Our measure for mobile ICT thus encompasses a range of devices which employees use to conduct their work-related tasks. As wireless connectivity has advanced considerably during recent years, so have the possibilities to remotely access relevant internal digital resources. Based on our estimation sample, Table A.3 shows the share of firms providing external access to internal digital resources along the distribution of the use of mobile ICT. These exemplary digital resources illustrate the functionality of mobile ICT and range from corporate email accounts, internal wikis or intranet, enterprise software, to internal network drives. Within the lowest (highest) tercile of the distribution of mobile ICT among employees, $60 \%$ (82\%) of firms enable remote access to the corporate email account and in roughly $40 \%$ (70\%) of firms employees can access enterprise software or internal network drives using mobile ICT remotely.

Since firms that use mobile ICT might also exhibit a high general ICT intensity, we have to differentiate the use of mobile ICT from other forms of ICT used in the workplace. Therefore, we measure the firms' general ICT intensity in terms of the share of employees who work predominantly with a computer (\% emp. working with $P C$ ). This measure is a common proxy for general purpose ICT and has been widely used in the ICT productivity literature (e.g. Bloom et al., 2012; Bresnahan et al., 2002). Finally, the firms' general

\footnotetext{
${ }^{5}$ We drop firms with sales of less than 10,000 euro (4 Observations) and more than one million euro (31 Observations) per employee. Since investment enters the empirical model in logarithmic form, for 46 observations with reported investment of zero we replace investments by the $10^{\text {th }}$ percentile of investments per employee in the corresponding industry multiplied by the number of employees in the firm.
} 
(mainly fixed-line) internet connectivity is measured by the share of employees who have access to the internet in the workplace (\% emp. internet access).

We measure the use of TBW and other flexible working arrangements in a similar fashion. Firms were asked whether they provide trust-based work time, i.e. self-reliant organisation of working time without formal records of hours kept by the company. In a follow-up question, we asked for the share of employees working under TBW arrangements. Since firms might be very heterogenous in terms of how intensive these arrangements are effectively used, we use this share as the measure of firms' use of TBW (\% emp. TBW). In our analysis, we want to distinguish the degree of employee autonomy embraced by TBW from that of more limited forms of workplace flexibility. Therefore, we also surveyed and control for the firms' share of employees with working time accounts (\% emp. WTA) and working from home arrangements (\% emp. WFH).

Following a standard approach in the estimation of production functions, we use data on sales as the output measure (Syverson, 2011). We measure labour in full-time equivalent terms, assuming that part-time employees constitute on average half of a full-time employee. As we do not observe capital inputs, we use investment expenditures to approximate capital, assuming that investments are proportional to the firms' capital stock (e.g. Bertschek and Kaiser, 2004; Raymond et al., 2015).

In addition, we include a rich set of control variables in all our estimations. The employees' abilities and skills are important determinants of productivity. Moreover, there is a large literature on skill-biased technological and organisational change documenting how technological progress and organisational change over past decades have favoured more educated and skilled workers (Autor et al., 2003; Black and Lynch, 2001; Caroli and Van Reenen, 2001; Entorf et al., 1999). We thus control for the skill profile of the workforce by including the share of employees with a university degree and the share of employees with a vocational education. Empirical evidence suggests that the age profile of the employees may be related to productivity and that older workers use ICT less than younger workers (Friedberg, 2003; Göbel and Zwick, 2012). Hence, we account for the age profile of the workforce by including the share of employees below the age of 30 into the empirical model. As discussed above, in Germany the works council is usually involved in organisational change related to working hours and compensation, such as the introduction of TBW. We thus include a binary indicator taking the value one if the firm has a works council established. Furthermore, we account for employees' workload as a potential confounding factor since arrangements involving high workplace flexibility and mobile ICT usage are often criticised for potentially increasing the employees' workload and leading to longer hours (Eurofound and International Labour Office, 2017). We employ the share of employees working overtime as a measure for the workload of a 
firm's employees. Taking the literature on the positive relation between productivity and export activities into account (e.g. Lileeva and Trefler, 2010), we control for the share of exports in total sales. Moreover, we include nine industry dummies constructed from two digit standard industry codes (NACE), which account for productivity dispersions, output prices, demand and other dispersions across industries. ${ }^{6}$ Finally, to account for well documented structural differences between East and West Germany, we include a dummy indicating whether the firm is located in East Germany. Further firm characteristics employed for sensitivity analyses are described in the respective sections.

\subsection{Descriptive Statistics}

Table 1 provides summary statistics for the main variables of our analysis. On average, the firms have 109 employees (in full-time equivalent terms) and achieved a sales volume of 19 million euros. Both values show that our sample largely consists of small- and mediumsized enterprises. The firms' average investment expenditures amount to 1 million euros and $26 \%$ of the employees have a university degree. In terms of firms' general ICT intensity, on average $62 \%$ of the employees work predominantly with a PC and $74 \%$ have access to the internet in the workplace.

« Table 1 about here »

On average, the employers have equipped a share of $33 \%$ of their employees with mobile ICT devices. Furthermore, on average $34 \%$ of the employees are entitled to work under TBW arrangements. ${ }^{7}$ Figure 2 depicts the use of mobile ICT and the incidence of TBW by industry among the firms in our sample. Mobile ICT is most commonly used in the ICT Services sector where over $60 \%$ of employees have been equipped with mobile ICT in the average firm. They have also widely diffused in consulting and advertising firms, as well as in the Technical Services sector, whereas they are least common in the Retail Trade sector. Figure 2 also demonstrates that the use of TBW is quite common over most service sectors. On average, around half of the employees in the ICT Services, Technical Services and the Consulting and Advertising industry are entitled to TBW. Again, they are least common in the Retail Trade industry. ${ }^{8}$ As Table A.4 makes evident, even within the industries we consider there is considerable heterogeneity in the diffusion of mobile

\footnotetext{
${ }^{6}$ In addition to heterogeneity across industries, there may be firm-specific prices which are unobserved. As we measure the dependent variable by sales, not physical output, the coefficients in the empirical model should be interpreted to reflect not only the technological parameters of the production function, but also the firms' market power (Bloom et al., 2012). We address this issue empirically in Section 5.2.2.

${ }^{7}$ In our estimation sample, $86 \%$ of the firms use mobile ICT and $59 \%$ of the firms use TBW in some way.

${ }^{8}$ Our main results are robust to the exclusion of ICT Services as well as the Retail Trade sector from the estimation sample.
} 
ICT and TBW. For the share of employees equipped with mobile ICT, the interquartile range amounts to $45 \%$ or more in many industries. The table also demonstrates that the distribution of TBW contains more extreme values of 0 and 1 , meaning that either the firm does not offer TBW at all, or all employees are actually working under TBW.

« Figure 2 about here »

\section{Results}

\subsection{Baseline Results}

Table 2 provides the estimation results of the production function model in Equation (3). In Column (1), we estimate a basic version of the production function including all basic control variables discussed above as well as the share of employees being equipped with mobile ICT (\% emp. mobile ICT) as the single measure of ICT use in the firm and the share of employees working under TBW (\% emp. TBW). The main effects of both variables of interest are positive, statistically significant and economically meaningful. Firms with a 10 percentage points higher share of employees equipped with mobile ICT exhibit a $1.19 \%$ higher output. Similarly, firms with a 10 percentage points higher share of employees working under TBW have a 1.02\% higher output. All other coefficients are in line with expectations. For instance, the share of high-skilled employees exhibits a higher output elasticity than the share of medium-skilled employees. Export intensity is strongly related to firms' output while the share of employees working overtime yields a statistically insignificant coefficient. In Column (2), we additionally include the share of employees working mainly with personal computers and the share of employees with access to the internet in order to differentiate mobile ICT from other, more general forms of ICT use in the workplace. The main effects of mobile ICT and TBW become insignificant, while the firms' general ICT intensity is positively and significantly related to the firms' output. Finally, in Column (3) we estimate the full baseline model according to Equation (3) in order to test for complementarity between mobile ICT and TBW. Our estimation result in this baseline model supports the complementarity hypothesis. The interaction between mobile ICT and TBW is positive, as well as statistically and economically significant. At the average utilisation of TBW in our estimation sample, an increase in the share of employees being equipped with mobile ICT by 20 percentage points is associated with a $1.5 \%$ increase in output $((-0.054+0.380 * 0.34) * 20)$. Similarly, an increase in the share of employees working under TBW by 20 percentage points is associated with a $1.15 \%$ increase in output at the average rate of mobile ICT use.

« Table 2 about here » 
In Table 3, we introduce further control variables for the prevalence of other forms of workplace flexibility into our model in order to differentiate TBW from more limited forms of temporal and spatial flexibility. We additionally control for the share of employees with working from home arrangements as well as for the share of employees with working time accounts. Overall, both types of workplace flexibility yield an insignificant main effect. More importantly, the respective pairwise interactions with mobile ICT yield a small and also statistically insignificant coefficient. In contrast, our previous results on the interaction between mobile ICT and TBW remain unchanged. The fact that the empirical results only support complementarity of mobile ICT with TBW suggests that it is the high degree of employee autonomy granted by TBW which is mutually reinforcing with mobile ICT, rather than more limited forms of workplace flexibility.

« Table 3 about here »

\subsection{Extensions and Robustness Tests}

So far, our results provide some initial indicative conditional correlations in support of the hypothesis of complementarity between mobile ICT and TBW. However, we must be cautious in interpreting our results due to common challenges in testing for complementarities (Athey and Stern, 1998).

First, instead of the joint adoption of mobile ICT and TBW affecting productivity, causality could potentially run in the opposite direction. For instance, firms with a positive productivity shock and improved cash flows might be more likely to invest in new technologies. Likewise, well-performing firms might be in a better position to offer their employees the amenity of workplace flexibility.

Second, our results could be driven by unobserved factors causing a correlation between mobile ICT, the adoption of TBW and productivity. A widely expressed concern in the literature is that unobserved good (human resource) management may be causing the joint adoption of new technologies and specific advanced management practices as well as their joint covariance with performance (Bloom and Van Reenen, 2011; Brynjolfsson and Hitt, 2000; Tambe et al., 2012).

Concerning the endogeneity of organisational practices in our model, we follow most of the literature and assume that organisational practices are quasi-fix over the short run. ${ }^{9}$ In this vein, we assume that firms' internal organisation only changed marginally during the short diffusion period of mobile ICT and does not constitute a choice variable in our model. In this sense, one can interpret our regressions as assessing whether firm differences in organisational design, which existed prior to the diffusion of mobile ICT,

\footnotetext{
${ }^{9}$ See the discussion in Section 3.
} 
affect the returns from using these technologies (Aral et al., 2012). Since one might still be concerned about endogeneity of mobile ICT in our production function, we conduct several sensitivity tests in the following.

\subsubsection{Management Quality and Technology-Skill Complementarity}

As a first robustness check of our results, we address the problem of omitted variable bias. In particular, we focus on the issue that the positive coefficient on the interaction term $(\delta)$ might pick up unobserved management and organisational practices other than workplace flexibility. Our data include information on additional 'modern' managerial practices, which have been used to assess the management quality of firms (Bloom and Reenen, 2007) and have frequently been analysed in the ICT productivity literature and the personnel economics literature (Bartel et al., 2007; Black and Lynch, 2001; Cappelli and Neumark, 2001; Ichniowski and Shaw, 2003; Ichniowski et al., 1997). These management practices differ from traditional hierarchical organisation and emphasise the decentralisation of decision authority, incentives and target setting, monitoring and multitasking. Besides workplace flexibility, they have been characteristic of organisational change that has taken place since the 1990s. We augment our model in Equation (3) by these management practices and their interactions with mobile ICT in order to contrast TBW from possibly confounding managerial and organisational practices that could bias our previous results.

Table A.6 provides summary statistics on the indicator variables for additional management and organisational practices we are able to take into account. We observe whether the firm rewards employees based on effort by the use of incentive pay. We moreover take into account the existence of business units with their own profit and loss responsibility, such as profit centres, which has been used to proxy general decentralisation of decision authority below central management in other studies (Acemoglu et al., 2007). We account for target setting and monitoring by the firms' use of regular objective agreements and written performance appraisals. Finally, we observe whether the firms make use of job rotation models to develop employees' functional flexibility.

In Column (1) of Table 4, we augment our baseline specifications by the binary indicators for the individual management practices. Only the use of incentive pay enters our production function with a positive and statistically significant coefficient, while the use of job rotation models yields a negative and significant estimate. In Column (2), we also include the interactions between mobile ICT and the additional measures on management practices. While the additional interaction terms are statistically insignificant, our previous results supporting the notion of complementarity between mobile ICT and TBW remain unaffected. Moreover, the coefficient for the interaction term between mobile ICT and TBW remains similar in magnitude to our baseline results. As the model 
in Column (2) includes many indicators for managerial and organisational practices, one might be worried that the insignificant interaction terms with mobile ICT are a result of a too rich model specification and multicollinearity. We thus aggregate the individual working practices into a management z-score, following a standard practice (e.g. Bresnahan et al., 2002; Tambe et al., 2012), which is motivated by the literature on 'systems of workplace innovations' (Ichniowski et al., 1996). In particular, we take the sum over all indicators which yield a positive estimate in Column (1) (all practices excluding job rotation models) and standardise this variable. ${ }^{10}$ This standardised management score is positively and significantly related to output (Column 3). An increase in the score by one standard deviation is associated with an $8.8 \%$ higher output. Reassuringly, its interaction with mobile ICT remains statistically insignificant.

\section{« Table 4 about here »}

In Table 5, we perform a further check of our main findings, referring to the literature on skill-biased technological and organisational change (Autor et al., 2003; Caroli and Van Reenen, 2001). While we accounted for the skill profile of the workforce throughout all our estimations, we now include an additional interaction term between the share of highskilled employees and the use of mobile ICT as well as TBW, respectively. We thereby test whether it is actually the simultaneous presence of a skilled workforce in firms using mobile ICT or TBW intensively that drives our findings. Again, the estimation results show that the coefficients for the additional interaction terms are insignificant, while our previous finding remains unaffected. We thus assume that our main finding does not merely reflect complementarity of mobile ICT or TBW with skills.

\section{« Table 5 about here »}

\subsubsection{Collinearity, Functional Form and Mark-Ups}

Additional robustness tests are included in Tables A.7 and A.8 in the appendix. As some key technological and organisational variables in our model exhibit non-negligible correlation, ${ }^{11}$ we mitigate potential multicollinearity by excluding the control variables measuring alternative use of ICT besides mobile ICT in Table A.7. We then assess interactions between the use of mobile ICT and TBW (Column 1), working from home arrangements (Column 2) and working time accounts (Column 3) in isolation. Our original

\footnotetext{
${ }^{10}$ Summing over the individual indicators for managerial and organisational practices to build an aggregate score implies that each practice is given equal weight in the indicator. This approach is justified by a test of equality of coefficients on the main effects of the individual practices in Column (1), which cannot reject equality. Standardisation is obtained by substracting the overall mean and dividing by the sample standard deviation (see e.g. Rasel, 2016).

${ }^{11}$ See Table A.5 for correlations among key variables.
} 
results hold and the interaction between mobile ICT and TBW yields the sole statistically significant coefficient. In Column 5 of the same table, we address potential functional form misspecification of our production function. In particular, we consider the full second order expansion in mobile ICT and TBW by adding their quadratic terms to the model. If the production function could in fact be approximated by this functional form, leaving out the squared variables might result in a spurious significant coefficient on the interaction term because the two potential complements are positively correlated. In addition, by including the squared terms we obtain insights into whether the use of mobile ICT or TBW entail diminishing marginal returns.

In Table A.8, we address the fact that we use sales data as output information so that our estimates might reflect firm-level differences in output prices resulting from differences in market power in addition to the technological parameters of the production function. We address this issue of differential mark-ups due to market concentration by including survey information on competitive pressure as perceived by the firm. Firms were asked how they assess their own competitiveness within their industry: average, above-, or below average. The information thus allows us to account for firm-level variation in contrast to frequently used strategies which apply competition indices that only vary at the sectoral level (Hottenrott et al., 2016). Overall, our estimation results show that our main result is not affected by the inclusion of these control variables. ${ }^{12}$

\subsubsection{Instrumental Variable Estimation}

Even though the data make it possible to account for multiple sources of heterogeneity between firms in the above regressions, the error term in the models might still pick up unobservables which are correlated with firms' decision to adopt mobile ICT and TBW as well as the firms' productivity. Additionally, our results above might still be subject to reverse causation. In order to explicitly account for potential endogeneity of mobile ICT in the production function, we perform an instrumental variable regression (IV) (Athey and Stern, 1998; Biesebroeck, 2007). In general, finding instrumental variables, which affect the firms' output only through the potentially endogenous ICT input, is challenging. As a fist step, we construct a measure for the average share of employees being equipped with mobile ICT within an industry and firm-size class. ${ }^{13}$ The potential costs and benefits of mobile ICT use differ between industries and firms of different sizes, rendering the within-cell average a relevant instrument. ${ }^{14}$ In addition, after we control for

\footnotetext{
${ }^{12}$ All other results not shown in Table A.8 are also robust to the inclusion of the perceived competitiveness measure but excluded for brevity.

${ }^{13} \mathrm{We}$ construct this average over 45 cells, made up of 9 industries and 5 size classes. The size classes are 5-19, 20-49, 50-249, 250-499 and $>=500$ employees.

${ }^{14}$ This instrumental variable approach follows for instance Bertschek and Niebel (2016) or Pfeifer (2016).
} 
the exact same industries as well as firm size in the production function, we can expect the average by sector and size class to be related to firms' output only through the potentially endogenous variable. Since we want to assess the exogeneity of our instrumental variable, we require additional instruments to test overidentifying restrictions.

For a second instrumental variable, we exploit the fact that interview partners in the survey were the firm's owner, senior manager, or the head of the IT department. Therefore, the interviewees can be expected to have a considerable influence on the firms' decisions to invest in mobile ICT. Similar to Bertschek and Niebel (2016), we use the years since the individual respondent first owned a private smartphone as a second instrument. Mobile electronic devices and applications first started proliferating among individuals before their diffusion in the business sector. The first year of smartphone ownership is therefore a good proxy for individual perception of the potential benefits and risks of mobile technologies. This instrument is valid, if the interviewees attitude towards mobile ICT is unrelated to other unobserved investment decisions by the firm. The information on private smartphone use is available for a subsample of 1,001 observations. Applying both instruments we compute the Hansen J-test statistic to assess the exogeneity of the instruments and the validity of our instrumental variable approach.

Table 6 provides the second stage results of our IV estimation. For comparison to our baseline results, Column (1) replicates the respective estimation for the slightly restricted sample. The results are comparable to our main finding in Table 2. Column (2) shows the results of the IV regression. ${ }^{15}$ The Kleibergen-Paap F-statistic suggests that the instruments are not weak. Moreover, the Hansen J-statistic is far away from the rejected area, thus supporting the exogeneity of the instruments. Looking at the point estimate on the interaction term between mobile ICT and TBW, our main results in support of complementarity are confirmed in the instrumental variable estimation.

« Table 6 about here »

\section{Conclusion}

We provide large-scale empirical evidence on the organisational complements to mobile information and communication technology (ICT), which constitutes one of the key technological innovations in the workplace in recent years. Our analysis based on an augmented production function framework supports the argument that the marginal benefit of adopting mobile ICT in the firm increases with the formal delegation of decision authority to employees regarding the entire structure of their workday by means of trust-based work

\footnotetext{
${ }^{15}$ The corresponding first stage regressions are shown in Table A.9 in the appendix.
} 
time arrangements (TBW). These results hold when we account for alternative forms of flexible work arrangements which provide more limited flexibility over the place of work, or the work schedule.

While our analysis is based on observational data, which always exacerbates a clear causal interpretation, our results are extremely consistent across different specifications, making use of rich information on alternative complements, such as employees' skills or alternative organisational practices, as well as instrumental variable estimation. Overall, we provide first direct empirical evidence on the interplay between mobile ICT and organisational practices, thereby contributing to a better understanding of the implications of contemporary technology for work arrangements and firm performance, especially in increasingly service-oriented economies.

Several mechanisms might lead to a system of mutually reinforcing complements formed by mobile ICT and the high degree of employee autonomy granted by TBW. On the one hand, mobile devices and infrastructure have enabled access to information technology which is uncoupled from standard workplaces and working hours. Therefore, mobile ICT can reduce information, coordination and communication costs within the firm, which would otherwise increase when employees start working autonomously under TBW. On the other hand, decentralisation involves principle agent problems, which might result in shirking and increased monitoring costs. This is especially the case when employees make effective use of mobile ICT by working outside regular workplaces and working hours, thereby limiting the firm's direct control over their work effort. TBW can serve as a means to address these problems by transitioning from monitoring employees' input to merely monitoring their output in a results-only working environment. Consequently, a simultaneous use of mobile ICT and TBW might help to reap the benefits and decrease the potential costs of one another.

Our analysis extends a vast empirical literature documenting how (information) technologies shape organisational practices and work arrangements. This literature, traditionally based on general investments in ICT and broad metrics of organisation, has found that firms realising benefits from ICT investments are those with complementary organisational decision rights. We extend this literature by providing another example of how specific types of work arrangements complement new technology. Our analysis thus informs managers by documenting how distinct autonomous work practices are relevant for firms making investments decisions in mobile ICT. As TBW implies a step towards greater autonomy compared to more classical forms of workplace flexibility, our results suggest that the degree of discretion of the employee matters in order to take advantage of these new technologies. For firms that are not already characterised by an appropriately high degree of employee autonomy over when and where they work, successful investment in 
mobile ICT can require additional investments in organisational change. Vice versa, our study underlines the importance of technology when firms want to align their organisation with increasing societal and economic needs for greater workplace flexibility.

Our study bears further implications for policy discussions. The results are in line with the notion that, as mobile ICT further advances and proliferates, it will favour work organisation based on high employee autonomy over the time and location of work and lead to a greater use of such organisational strategies. As of right now, national regulations in many industrialised countries do not directly address such flexible work schedules. As workplace flexibility carries opportunities as well as risks for employers and employees, demands for active regulation which serves the interest of both groups might accelerate as the importance of such work practices continues to grow. 


\section{$7 \quad$ Tables and Figures}

Figure 1: Recent Decentralisation of Computing Technologies in German Firms

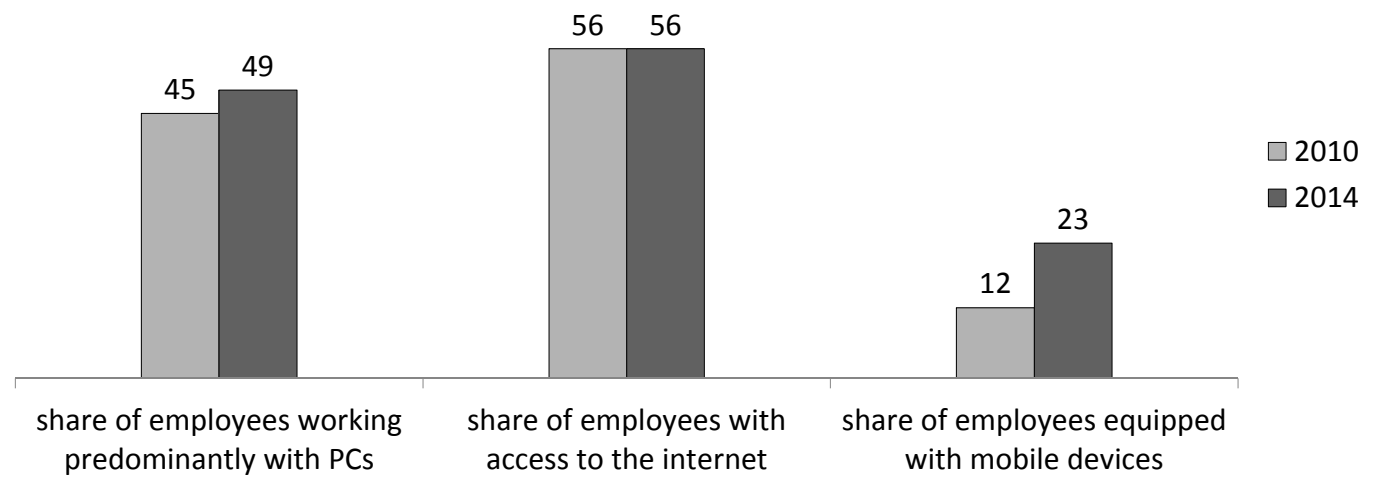

Note: Figures are representative of firms with at least five employees in the manufacturing sector and selected service industries in Germany. Source: Centre for European Economic Research (ZEW) (2015)

Figure 2: Mobile ICT and TBW by Industry, Estimation Sample

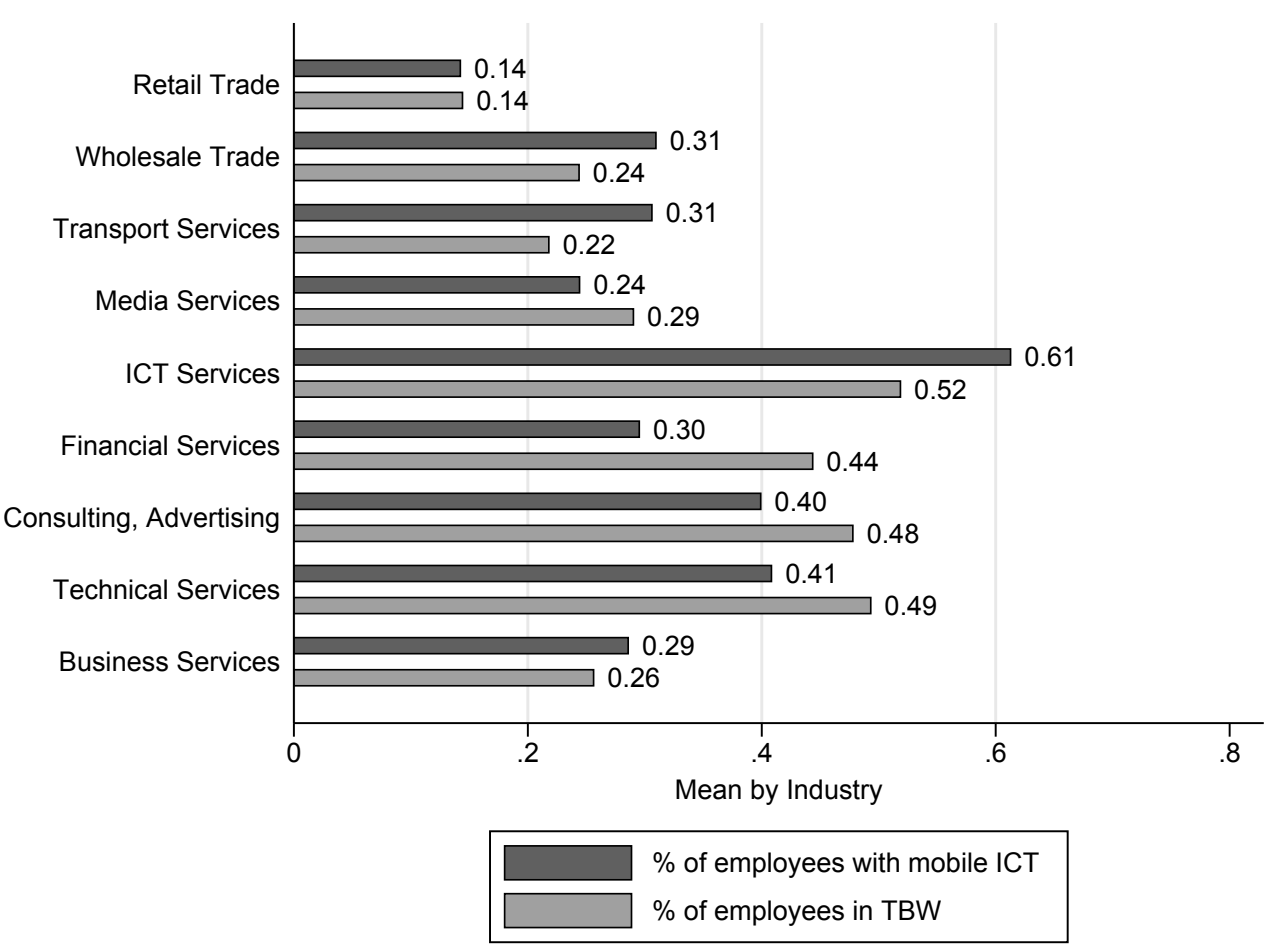

Note: Based on 1,045 observations in the estimation sample. Source: ZEW ICT-Survey 2015. 
Table 1: Summary Statistics of Key Variables in Estimation Sample

\begin{tabular}{|c|c|c|c|c|}
\hline & Mean & $\mathrm{SD}$ & Min & Max \\
\hline \multicolumn{5}{|l|}{ Output } \\
\hline sales (in million Euro) & 19.00 & 187.38 & 0.05 & 5600.00 \\
\hline \multicolumn{5}{|l|}{ ICT Use } \\
\hline$\%$ emp. mobile ICT & 0.33 & 0.33 & 0 & 1 \\
\hline$\%$ emp. working with PC & 0.62 & 0.37 & 0 & 1 \\
\hline$\%$ emp. internet access & 0.74 & 0.35 & 0 & 1 \\
\hline \multicolumn{5}{|l|}{ Workplace Flexibility } \\
\hline$\%$ emp. TBW & 0.34 & 0.42 & 0 & 1 \\
\hline$\%$ emp. WTA & 0.51 & 0.46 & 0 & 1 \\
\hline$\%$ emp. WFH & 0.14 & 0.23 & 0 & 1 \\
\hline \multicolumn{5}{|l|}{ Qualification and Age Structure } \\
\hline$\%$ high-skilled emp. & 0.26 & 0.29 & 0 & 1 \\
\hline$\%$ medium-skilled emp. & 0.59 & 0.29 & 0 & 1 \\
\hline$\%$ emp. under 30 & 0.24 & 0.18 & 0 & 1 \\
\hline \multicolumn{5}{|l|}{ Controls } \\
\hline employees (full-time equivalent) & 109.06 & 568.76 & 1 & 12375 \\
\hline investments (in million Euro) & 0.96 & 4.53 & 0 & 90 \\
\hline export share & 0.05 & 0.15 & 0 & 1 \\
\hline$\%$ emp. overtime & 0.48 & 0.36 & 0 & 1 \\
\hline works council & 0.18 & 0.39 & 0 & 1 \\
\hline located in East Germany & 0.29 & 0.45 & 0 & 1 \\
\hline Observations & 1045 & & & \\
\hline
\end{tabular}

Source: ZEW ICT-Survey 2015. 
Table 2: Baseline Regression Results

\begin{tabular}{|c|c|c|c|}
\hline & \multicolumn{3}{|c|}{ Dependent Variable: $\ln ($ sales $)$} \\
\hline & $(1)$ & $(2)$ & $(3)$ \\
\hline$\%$ emp. mobile ICT & $\begin{array}{l}0.119^{*} \\
(0.069)\end{array}$ & $\begin{array}{c}0.111 \\
(0.069)\end{array}$ & $\begin{array}{l}-0.054 \\
(0.090)\end{array}$ \\
\hline$\%$ emp. TBW & $\begin{array}{l}0.102^{* *} \\
(0.051)\end{array}$ & $\begin{array}{c}0.084 \\
(0.052)\end{array}$ & $\begin{array}{l}-0.068 \\
(0.077)\end{array}$ \\
\hline$\%$ emp. $\mathrm{MICT} * \%$ emp. TBW & & & $\begin{array}{c}0.380^{* * *} \\
(0.137)\end{array}$ \\
\hline$\%$ emp. working with PC & & $\begin{array}{l}0.230^{* *} \\
(0.092)\end{array}$ & $\begin{array}{c}0.241^{* * *} \\
(0.092)\end{array}$ \\
\hline$\%$ emp. internet access & & $\begin{array}{l}-0.024 \\
(0.083)\end{array}$ & $\begin{array}{l}-0.006 \\
(0.083)\end{array}$ \\
\hline $\ln$ (employees) & $\begin{array}{c}0.921^{* * *} \\
(0.022)\end{array}$ & $\begin{array}{c}0.924^{* * *} \\
(0.022)\end{array}$ & $\begin{array}{c}0.925^{* * *} \\
(0.022)\end{array}$ \\
\hline $\ln ($ investment $)$ & $\begin{array}{c}0.098^{* * *} \\
(0.014)\end{array}$ & $\begin{array}{c}0.096^{* * *} \\
(0.014)\end{array}$ & $\begin{array}{c}0.095^{* * *} \\
(0.014)\end{array}$ \\
\hline$\%$ high-skilled emp. & $\begin{array}{c}0.471^{* * *} \\
(0.124)\end{array}$ & $\begin{array}{c}0.353^{* * *} \\
(0.131)\end{array}$ & $\begin{array}{c}0.361^{* * *} \\
(0.130)\end{array}$ \\
\hline$\%$ medium-skilled emp. & $\begin{array}{c}0.287^{* * *} \\
(0.111)\end{array}$ & $\begin{array}{l}0.230^{* *} \\
(0.112)\end{array}$ & $\begin{array}{c}0.244^{* *} \\
(0.113)\end{array}$ \\
\hline$\%$ emp. under 30 & $\begin{array}{l}-0.013 \\
(0.121)\end{array}$ & $\begin{array}{l}-0.023 \\
(0.119)\end{array}$ & $\begin{array}{l}-0.024 \\
(0.118)\end{array}$ \\
\hline works council & $\begin{array}{c}0.015 \\
(0.064)\end{array}$ & $\begin{array}{c}0.018 \\
(0.064)\end{array}$ & $\begin{array}{c}0.015 \\
(0.063)\end{array}$ \\
\hline export share & $\begin{array}{c}0.732^{* * *} \\
(0.140)\end{array}$ & $\begin{array}{c}0.715^{* * *} \\
(0.136)\end{array}$ & $\begin{array}{c}0.705^{* * *} \\
(0.135)\end{array}$ \\
\hline$\%$ emp. overtime & $\begin{array}{c}0.065 \\
(0.053)\end{array}$ & $\begin{array}{c}0.062 \\
(0.053)\end{array}$ & $\begin{array}{c}0.056 \\
(0.053)\end{array}$ \\
\hline constant & $\begin{array}{c}-1.640^{* * *} \\
(0.135)\end{array}$ & $\begin{array}{c}-1.668^{* * *} \\
(0.138)\end{array}$ & $\begin{array}{c}-1.668^{* * *} \\
(0.137)\end{array}$ \\
\hline Industry \& Regional Dummies & Yes & Yes & Yes \\
\hline $\begin{array}{l}\text { Adjusted } \mathrm{R}^{2} \\
\text { Observations }\end{array}$ & $\begin{array}{c}0.856 \\
1045\end{array}$ & $\begin{array}{l}0.857 \\
1045\end{array}$ & $\begin{array}{c}0.858 \\
1045\end{array}$ \\
\hline
\end{tabular}

Note: OLS estimations. Standard errors in parentheses robust to heteroskedasticity. ${ }^{*} p<.10,{ }^{* *} p<.05,{ }^{* * *} p<.01$. 
Table 3: Baseline Results: Controlling for Alternative Workplace Flexibility Practices

\begin{tabular}{|c|c|c|c|c|c|}
\hline & \multicolumn{5}{|c|}{ Dependent Variable: $\ln ($ sales) } \\
\hline & $(1)$ & $(2)$ & $(3)$ & $(4)$ & $(5)$ \\
\hline$\%$ emp. mobile ICT & $\begin{array}{l}-0.065 \\
(0.090)\end{array}$ & $\begin{array}{c}-0.069 \\
(0.092)\end{array}$ & $\begin{array}{l}-0.055 \\
(0.090)\end{array}$ & $\begin{array}{l}-0.094 \\
(0.111)\end{array}$ & $\begin{array}{l}-0.108 \\
(0.112)\end{array}$ \\
\hline$\%$ emp. TBW & $\begin{array}{l}-0.066 \\
(0.077)\end{array}$ & $\begin{array}{l}-0.063 \\
(0.078)\end{array}$ & $\begin{array}{c}-0.069 \\
(0.077)\end{array}$ & $\begin{array}{l}-0.070 \\
(0.077)\end{array}$ & $\begin{array}{l}-0.065 \\
(0.078)\end{array}$ \\
\hline$\%$ emp. MICT * \% emp. TBW & $\begin{array}{c}0.351^{* *} \\
(0.143)\end{array}$ & $\begin{array}{c}0.345^{* *} \\
(0.150)\end{array}$ & $\begin{array}{c}0.381^{* * *} \\
(0.137)\end{array}$ & $\begin{array}{c}0.382^{* * *} \\
(0.137)\end{array}$ & $\begin{array}{l}0.348^{* *} \\
(0.150)\end{array}$ \\
\hline$\%$ emp. WFH & $\begin{array}{c}0.117 \\
(0.110)\end{array}$ & $\begin{array}{c}0.083 \\
(0.192)\end{array}$ & & & $\begin{array}{c}0.090 \\
(0.192)\end{array}$ \\
\hline$\%$ emp. MICT $* \%$ emp. WFH & & $\begin{array}{c}0.050 \\
(0.246)\end{array}$ & & & $\begin{array}{c}0.040 \\
(0.246)\end{array}$ \\
\hline$\%$ emp. WTA & & & $\begin{array}{l}-0.023 \\
(0.043)\end{array}$ & $\begin{array}{l}-0.049 \\
(0.060)\end{array}$ & $\begin{array}{c}-0.049 \\
(0.060)\end{array}$ \\
\hline$\%$ emp. MICT * \% emp. WTA & & & & $\begin{array}{c}0.075 \\
(0.120)\end{array}$ & $\begin{array}{c}0.072 \\
(0.120)\end{array}$ \\
\hline Controls & Yes & Yes & Yes & Yes & Yes \\
\hline Adjusted $\mathrm{R}^{2}$ & 0.858 & 0.857 & 0.857 & 0.857 & 0.857 \\
\hline Observations & 1045 & 1045 & 1045 & 1045 & 1045 \\
\hline
\end{tabular}

Note: OLS estimations. All columns include controls for capital, labour, industry and regional dummies, general ICT-intensity and internet use, the skill and age profile of the workforce, the incidence of overtime, the firm's export share, the presence of a works council and a constant (not shown but available upon request). Standard errors in parentheses robust to heteroskedasticity. ${ }^{*} p<.10,{ }^{* *} p<.05,{ }^{* * *} p<.01$. 
Table 4: Robustness Test: Management Practices

\begin{tabular}{|c|c|c|c|c|c|c|}
\hline \multirow[b]{3}{*}{$\%$ emp. mobile ICT } & \multicolumn{6}{|c|}{ Dependent Variable: $\ln$ (sales) } \\
\hline & \multicolumn{2}{|c|}{ (1) } & \multicolumn{2}{|c|}{$(2)$} & \multicolumn{2}{|c|}{$(3)$} \\
\hline & -0.097 & $(0.093)$ & -0.081 & $(0.123)$ & -0.091 & $(0.092)$ \\
\hline$\%$ emp. TBW & -0.073 & $(0.076)$ & -0.073 & $(0.076)$ & -0.072 & $(0.076)$ \\
\hline$\%$ emp. $\mathrm{MICT} * \%$ emp. TBW & $0.380^{* * *}$ & $(0.137)$ & $0.385^{* * *}$ & $(0.137)$ & $0.378^{* * *}$ & $(0.137)$ \\
\hline incentive pay (IP) & $0.111^{* * *}$ & $(0.041)$ & $0.109^{*}$ & $(0.058)$ & & \\
\hline job rotation (JR) & $-0.115^{* *}$ & $(0.048)$ & -0.078 & $(0.069)$ & & \\
\hline profit center (PR) & 0.066 & $(0.047)$ & 0.071 & $(0.068)$ & & \\
\hline objective agreements (OA) & 0.035 & $(0.052)$ & 0.031 & $(0.071)$ & & \\
\hline performance appraisals (PA) & 0.045 & $(0.051)$ & 0.047 & $(0.071)$ & & \\
\hline$\%$ emp. $\mathrm{MICT}^{*} \mathrm{IP}$ & & & 0.008 & $(0.123)$ & & \\
\hline$\%$ emp. $\mathrm{MICT}^{*} \mathrm{JR}$ & & & -0.116 & $(0.161)$ & & \\
\hline$\%$ emp. $\mathrm{MICT}^{*} \mathrm{PR}$ & & & -0.014 & $(0.139)$ & & \\
\hline$\%$ emp. $\mathrm{MICT}^{*} \mathrm{OA}$ & & & 0.013 & $(0.156)$ & & \\
\hline$\%$ emp. $\mathrm{MICT}^{*} \mathrm{PA}$ & & & -0.009 & $(0.153)$ & & \\
\hline Management Score & & & & & $0.088^{* * *}$ & $(0.033)$ \\
\hline$\%$ emp. MICT * MM Score & & & & & -0.010 & $(0.064)$ \\
\hline Controls & Yes & & Yes & & Yes & \\
\hline Adjusted $R^{2}$ & 0.859 & & 0.859 & & 0.859 & \\
\hline Observations & 1045 & & 1045 & & 1045 & \\
\hline
\end{tabular}

Note: OLS estimations. All columns include controls for capital, labour, industry and regional dummies, general ICT-intensity and internet use, the skill and age profile of the workforce, the incidence of overtime, the firm's export share, the presence of a works council and a constant (not shown but available upon request). Standard errors in parentheses robust to heteroskedasticity. ${ }^{*} p<.10,{ }^{* *} p<.05,{ }^{* * *} p<.01$.

Table 5: Robustness Test: Skill Complementarity

\begin{tabular}{lcccc}
\hline \hline & \multicolumn{4}{c}{ Dependent Variable: $\ln ($ sales $)$} \\
\cline { 2 - 5 } & \multicolumn{5}{c}{$(1)$} & & $(2)$ \\
\hline \% emp. mobile ICT & -0.019 & $(0.104)$ & -0.077 & $(0.092)$ \\
\% emp. TBW & -0.079 & $(0.079)$ & -0.037 & $(0.085)$ \\
\% emp. MICT * \% emp. TBW & $0.406^{* * *}$ & $(0.144)$ & $0.428^{* * *}$ & $(0.144)$ \\
$\%$ high-skilled emp. (HSE) & $0.429^{* * *}$ & $(0.157)$ & $0.434^{* * *}$ & $(0.145)$ \\
$\%$ emp. MICT * \% HSE & -0.140 & $(0.194)$ & & $(0.152)$ \\
\% emp. TBW * \% HSE & & & -0.154 & \\
Controls & Yes & & Yes & \\
\hline Adjusted R & 0.857 & & 0.857 & \\
Observations & 1045 & & 1045 & \\
\hline \hline
\end{tabular}

Note: OLS estimations. All columns include controls for capital, labour, industry and regional dummies, general ICT-intensity and internet use, age profile of the workforce, the incidence of overtime, the firm's export share, the presence of a works council and a constant (not shown but available upon request). Standard errors in parentheses robust to heteroskedasticity. ${ }^{*} p<.10,{ }^{* *} p<.05,{ }^{* * *} p<.01$. 
Table 6: IV Estimation - Second Stage Regression

\begin{tabular}{lcccc}
\hline \hline & \multicolumn{4}{c}{ Dependent Variable: $\ln ($ sales $)$} \\
\cline { 2 - 5 } & \multicolumn{3}{c}{$(1)$} & \multicolumn{2}{c}{$(2)$} \\
OLS & IV \\
\hline \% emp. mobile ICT & -0.000 & $(0.091)$ & 0.465 & $(0.384)$ \\
\% emp. TBW & -0.043 & $(0.077)$ & -0.258 & $(0.164)$ \\
\% emp. MICT * \% emp. TBW & $0.314^{* *}$ & $(0.139)$ & $0.731^{* *}$ & $(0.357)$ \\
\% emp. working with PC & $0.220^{* *}$ & $(0.097)$ & $0.267^{* * *}$ & $(0.103)$ \\
\% emp. internet access & -0.009 & $(0.087)$ & -0.146 & $(0.125)$ \\
ln(employees) & $0.928^{* * *}$ & $(0.022)$ & $0.963^{* * *}$ & $(0.029)$ \\
ln(investment) & $0.093^{* * *}$ & $(0.014)$ & $0.079^{* * *}$ & $(0.016)$ \\
\% high-skilled emp. & $0.337^{* *}$ & $(0.136)$ & 0.143 & $(0.183)$ \\
\% medium-skilled emp. & $0.235^{* *}$ & $(0.114)$ & $0.239^{* *}$ & $(0.116)$ \\
\% emp. under 30 & -0.054 & $(0.118)$ & -0.056 & $(0.124)$ \\
works council & 0.011 & $(0.065)$ & 0.031 & $(0.067)$ \\
export share & $0.697^{* * *}$ & $(0.142)$ & $0.719^{* * *}$ & $(0.145)$ \\
\% emp. overtime & 0.075 & $(0.054)$ & 0.071 & $(0.058)$ \\
constant & $-1.669^{* * *}$ & $(0.140)$ & $-1.780^{* * *}$ & $(0.154)$ \\
Industry \& Regional Dummies & Yes & & Yes & \\
\hline Adjusted $R^{2}$ & 0.857 & & & \\
Kleibergen-Paap F-stat. & & & 10.601 & \\
Hansen J-test (P-value) & 1001 & & 0.581 & \\
Observations & \multicolumn{3}{c}{1001} & \\
\hline \hline
\end{tabular}

Note: OLS estimation in Column (1) and GMM estimation in Column (2). Standard errors in parentheses robust to heteroskedasticity. ${ }^{*} p<.10,{ }^{* *} p<.05,{ }^{* * *} p<.01$. 


\section{Appendix}

Table A.1: Industry Distribution in Estimation Sample and Full Sample

\begin{tabular}{llccccr}
\hline \multirow{2}{*}{ Industry } & NACE Rev. 2 & \multicolumn{2}{c}{ Estimation Sample } & & \multicolumn{2}{c}{ Full Sample } \\
\cline { 3 - 4 } \cline { 5 - 6 } & & $\mathrm{N}$ & $\%$ & & $\mathrm{~N}$ & \multicolumn{2}{c}{$\%$} \\
\hline Retail Trade & 45,47 & 127 & 12.2 & & 228 & 11.9 \\
Wholesale Trade & 46 & 98 & 9.4 & & 193 & 10.1 \\
Transport Services & $49-53,79$ & 122 & 11.7 & & 217 & 11.3 \\
Media Services & $18,58-60$ & 93 & 8.9 & & 164 & 8.5 \\
ICT Services & $61-63$ & 112 & 10.7 & & 223 & 11.6 \\
Financial Services & $64-66$ & 110 & 10.5 & & 231 & 12.0 \\
Consulting, Advertising & $69,702,73$ & 135 & 12.9 & & 231 & 12.0 \\
Technical Services & $71-72$ & 110 & 10.5 & & 191 & 10.0 \\
Business Services & $74,78,80-82$ & 138 & 13.2 & & 242 & 12.6 \\
\hline Total & & 1045 & 100 & & 1920 & 100 \\
\hline \hline
\end{tabular}

Source: ZEW ICT-Survey 2015. 
Table A.2: Variable Descriptions

\begin{tabular}{|c|c|}
\hline Variable & Description/Question \\
\hline \multicolumn{2}{|l|}{ Dependent variable } \\
\hline $\ln ($ sales $)$ & \multirow[t]{2}{*}{ logarithm of sales (in million euro) } \\
\hline ICT use & \\
\hline \% emp. mobile ICT & $\begin{array}{l}\text { What percentage of your employees have been equipped with mobile } \\
\text { devices with wireless internet access, such as notebooks, tablets and } \\
\text { smartphones? }\end{array}$ \\
\hline$\%$ emp. working with PC & $\begin{array}{l}\text { What percentage of your employees work predominantly with a com- } \\
\text { puter in the workplace? }\end{array}$ \\
\hline$\%$ emp. internet access & $\begin{array}{l}\text { What percentage of your employees have access to the internet in the } \\
\text { workplace? }\end{array}$ \\
\hline \multicolumn{2}{|l|}{ Workplace flexibility } \\
\hline$\%$ emp. TBW & $\begin{array}{l}\text { Does your company use trust-based work time, i.e. self-reliant organ- } \\
\text { isation of working time without the company recording the number } \\
\text { of hours worked? To what percentage of employees do these arrange- } \\
\text { ments apply? }\end{array}$ \\
\hline \% emp. WTA & $\begin{array}{l}\text { Are there any regulations in your company related to working time } \\
\text { accounts, i.e. anything in between flextime and annual working hours } \\
\text { agreements? To what percentage do these arrangements apply? }\end{array}$ \\
\hline$\%$ emp. WFH & $\begin{array}{l}\text { Do you offer your employees the opportunity to work from home regu- } \\
\text { larly, so called working from home arrangements? To what percentage } \\
\text { do these arrangements apply? }\end{array}$ \\
\hline \multicolumn{2}{|l|}{ Qualification and age } \\
\hline$\%$ high-skilled emp. & $\begin{array}{l}\text { Share of employees holding a university, college or polytechnical de- } \\
\text { gree }\end{array}$ \\
\hline$\%$ medium-skilled emp. & $\begin{array}{l}\text { Share of employees with an apprenticeship or holding a technical de- } \\
\text { grees }\end{array}$ \\
\hline$\%$ emp. under 30 & Share of employees under the age of 30 \\
\hline \multicolumn{2}{|r|}{ (1) } \\
\hline \% emp. overtime & $\begin{array}{l}\text { What percentage of your employees have worked overtime in the pre- } \\
\text { vious year? Overtime is defined as extra work performed exceeding } \\
\text { the agreed weekly working hours. }\end{array}$ \\
\hline \multicolumn{2}{|l|}{ Management practices } \\
\hline \multicolumn{2}{|c|}{ Does your company employ any of the following human resource management practices? } \\
\hline incentive pay & Performance-related pay \\
\hline job rotation & Job rotation \\
\hline profit center & Cost/profit autonomy, profit centers \\
\hline objective agreements & Regular written objective agreements \\
\hline performance appraisals & Regular written performance appraisals \\
\hline \multicolumn{2}{|l|}{ Market concentration } \\
\hline competitiveness & $\begin{array}{l}\text { How do you assess the competitiveness of your company compared } \\
\text { to other companies in your industry? [above average, average, below } \\
\text { average] }\end{array}$ \\
\hline \multicolumn{2}{|l|}{ Instrumental variables } \\
\hline years of smartphone use & $\begin{array}{l}\text { Number of years the interviewee personally owned a smartphone be- } \\
\text { fore 2015. Based on the question: In which year did you buy your } \\
\text { first smartphone? }\end{array}$ \\
\hline average MICT (industry/size) & $\begin{array}{l}\text { Average share of employees equipped with mobile ICT within an in- } \\
\text { dustry and firm-size class (i.e. } 45 \text { cells, made up of } 9 \text { industries and } 5 \\
\text { size classes). }\end{array}$ \\
\hline
\end{tabular}

Source: ZEW ICT-Survey 2015. 
Table A.3: Provision of External Access by Usage of Mobile ICT

\begin{tabular}{lccc}
\hline \hline & $\begin{array}{c}\text { Lowest Tercile } \\
\text { \% emp. MICT }\end{array}$ & $\begin{array}{c}\text { Middle Tercile } \\
\text { \% emp. MICT }\end{array}$ & $\begin{array}{c}\text { Highest Tercile } \\
\text { \% emp. MICT }\end{array}$ \\
\cline { 2 - 4 } & Mean & Mean & Mean \\
\hline external access to corporate email-account & 0.60 & 0.79 & 0.82 \\
external access to wiki/intranet & 0.36 & 0.53 & 0.60 \\
external access to corporate software & 0.39 & 0.56 & 0.66 \\
external access to corporate networks & 0.44 & 0.58 & 311 \\
\hline Observations & 346 & 365 & 369 \\
\hline \hline
\end{tabular}

Source: ZEW ICT-Survey 2015.

Table A.4: Distribution of Key Variables by Industry

\begin{tabular}{|c|c|c|c|c|c|}
\hline Industry & Variable & Mean & $25^{t h}$ & Median & $75^{t h}$ \\
\hline \multirow{2}{*}{ Retail Trade } & \% emp. mobile ICT & 0.14 & 0.00 & 0.09 & 0.20 \\
\hline & $\%$ emp. TBW & 0.14 & 0.00 & 0.00 & 0.10 \\
\hline \multirow{2}{*}{ Wholesale Trade } & $\%$ emp. mobile ICT & 0.31 & 0.11 & 0.20 & 0.50 \\
\hline & $\%$ emp. TBW & 0.24 & 0.00 & 0.10 & 0.30 \\
\hline \multirow{2}{*}{ Transport Services } & $\%$ emp. mobile ICT & 0.31 & 0.05 & 0.15 & 0.50 \\
\hline & $\%$ emp. TBW & 0.22 & 0.00 & 0.00 & 0.25 \\
\hline \multirow{2}{*}{ Media Services } & $\%$ emp. mobile ICT & 0.24 & 0.03 & 0.17 & 0.35 \\
\hline & $\%$ emp. TBW & 0.29 & 0.00 & 0.08 & 0.41 \\
\hline \multirow{2}{*}{ ICT Services } & $\%$ emp. mobile ICT & 0.61 & 0.30 & 0.60 & 1.00 \\
\hline & $\%$ emp. TBW & 0.52 & 0.00 & 0.50 & 1.00 \\
\hline \multirow{2}{*}{ Financial Services } & $\%$ emp. mobile ICT & 0.30 & 0.05 & 0.20 & 0.50 \\
\hline & $\%$ emp. TBW & 0.44 & 0.00 & 0.28 & 1.00 \\
\hline \multirow{2}{*}{ Consulting, Advertising } & $\%$ emp. mobile ICT & 0.40 & 0.10 & 0.29 & 0.70 \\
\hline & $\%$ emp. TBW & 0.48 & 0.00 & 0.34 & 1.00 \\
\hline \multirow{2}{*}{ Technical Services } & $\%$ emp. mobile ICT & 0.41 & 0.15 & 0.33 & 0.67 \\
\hline & $\%$ emp. TBW & 0.49 & 0.00 & 0.40 & 1.00 \\
\hline \multirow{2}{*}{ Business Services } & \% emp. mobile ICT & 0.29 & 0.05 & 0.15 & 0.45 \\
\hline & $\%$ emp. TBW & 0.26 & 0.00 & 0.05 & 0.40 \\
\hline \multirow{2}{*}{ Total } & $\%$ emp. mobile ICT & 0.33 & 0.07 & 0.20 & 0.50 \\
\hline & $\%$ emp. TBW & 0.34 & 0.00 & 0.10 & 0.85 \\
\hline
\end{tabular}

Source: ZEW ICT-Survey 2015. 
Table A.5: Raw Correlations of Key Variables

\begin{tabular}{|c|c|c|c|c|c|}
\hline & $\begin{array}{c}\% \text { emp. } \\
\text { mobile } \\
\text { ICT }\end{array}$ & $\begin{array}{l}\% \text { emp. } \\
\text { working } \\
\text { with PC }\end{array}$ & $\begin{array}{c}\% \text { emp. } \\
\text { internet } \\
\text { access }\end{array}$ & $\begin{array}{l}\% \text { emp. } \\
\text { TBW }\end{array}$ & $\begin{array}{c}\% \text { emp. } \\
\text { WFH }\end{array}$ \\
\hline$\%$ emp. mobile ICT & 1 & & & & \\
\hline$\%$ emp. working with PC & $0.294^{* * *}$ & 1 & & & \\
\hline$\%$ emp. internet access & $0.355^{* * *}$ & $0.736^{* * *}$ & 1 & & \\
\hline$\%$ emp. TBW & $0.295^{* * *}$ & $0.340^{* * *}$ & $0.318^{* * *}$ & 1 & \\
\hline$\%$ emp. WFH & $0.484^{* * *}$ & $0.296^{* * *}$ & $0.304^{* * *}$ & $0.337^{* * *}$ & 1 \\
\hline$\%$ emp. WTA & -0.029 & $0.084^{* * *}$ & $0.089^{* * *}$ & -0.028 & 0.020 \\
\hline
\end{tabular}

Source: ZEW ICT-Survey 2015.

Table A.6: Descriptive Statistics of Additional Variables

\begin{tabular}{|c|c|c|c|c|c|}
\hline & Mean & $\mathrm{SD}$ & Min & Max & $\mathrm{N}$ \\
\hline \multicolumn{6}{|l|}{ Management Practices } \\
\hline incentive pay & 0.50 & 0.50 & 0 & 1 & 1045 \\
\hline job rotation & 0.19 & 0.39 & 0 & 1 & 1045 \\
\hline profit center & 0.31 & 0.46 & 0 & 1 & 1045 \\
\hline objective agreements & 0.44 & 0.50 & 0 & 1 & 1045 \\
\hline performance appraisals & 0.38 & 0.49 & 0 & 1 & 1045 \\
\hline \multicolumn{6}{|l|}{ Market Concentration } \\
\hline competitiveness & 1.52 & 0.54 & 1 & 3 & 1045 \\
\hline \multicolumn{6}{|l|}{ Instrumental Variables } \\
\hline years of smartphone use & 5.47 & 4.13 & 0 & 22 & 1001 \\
\hline average MICT (industry/size) & 0.34 & 0.15 & 0 & 1 & 1001 \\
\hline
\end{tabular}

Source: ZEW ICT-Survey 2015. 
Table A.7: Robustness Test: Parsimonious Model and Functional Form Specification

\begin{tabular}{|c|c|c|c|c|c|c|c|c|}
\hline \multirow{11}{*}{$\begin{array}{l}\% \text { emp. mobile ICT } \\
\% \text { emp. TBW } \\
\% \text { emp. MICT } * \% \text { emp. TBW } \\
\% \text { emp. WFH } \\
\% \text { emp. MICT } * \% \text { emp. WFH } \\
\% \text { emp. WTA } \\
\% \text { emp. MICT } * \% \text { emp. WTA } \\
(\% \text { emp. MICT })^{2} \\
(\% \text { emp. TBW })^{2}\end{array}$} & \multicolumn{8}{|c|}{ Dependent Variable: $\ln ($ sales $)$} \\
\hline & \multicolumn{2}{|c|}{ (1) } & \multicolumn{2}{|c|}{$(2)$} & \multicolumn{2}{|c|}{$(3)$} & \multicolumn{2}{|c|}{$(4)$} \\
\hline & -0.025 & $(0.089)$ & 0.078 & $(0.079)$ & 0.097 & $(0.096)$ & 0.253 & $(0.230)$ \\
\hline & -0.032 & $(0.075)$ & & & & & 0.241 & $(0.251)$ \\
\hline & $0.339^{* *}$ & $(0.136)$ & & & & & $0.399^{* * *}$ & $(0.142)$ \\
\hline & & & 0.098 & $(0.187)$ & & & & \\
\hline & & & 0.132 & $(0.232)$ & & & & \\
\hline & & & & & -0.040 & $(0.060)$ & & \\
\hline & & & & & 0.078 & $(0.123)$ & & \\
\hline & & & & & & & -0.312 & $(0.226)$ \\
\hline & & & & & & & -0.304 & $(0.250)$ \\
\hline PC usage \& Internet access & No & & No & & No & & No & \\
\hline Other Controls & Yes & & Yes & & Yes & & Yes & \\
\hline Adjusted $\mathrm{R}^{2}$ & 0.856 & & 0.855 & & 0.855 & & 0.857 & \\
\hline Observations & 1045 & & 1045 & & 1045 & & 1045 & \\
\hline
\end{tabular}

Note: OLS estimations. Columns 1-3 mitigate collinearity by omitting controls for PC and internet usage. Column 4 additionally controls for squared terms of mobile ICT and trust-based work time. All columns include controls for capital, labour, industry and regional dummies, the skill and age profile of the workforce, the incidence of overtime, the firm's export share, the presence of a works council and a constant (not shown but available upon request). Standard errors in parentheses robust to heteroskedasticity. ${ }^{*} p<.10,{ }^{* *} p<.05,{ }^{* * *} p<.01$.

Table A.8: Robustness Test: Controlling for Market Concentration

\begin{tabular}{|c|c|c|c|c|c|c|}
\hline \multirow[b]{3}{*}{$\%$ emp. mobile ICT } & \multicolumn{6}{|c|}{ Dependent Variable: $\ln$ (sales) } \\
\hline & \multicolumn{2}{|c|}{$(1)$} & \multicolumn{2}{|c|}{$(2)$} & \multicolumn{2}{|c|}{$(3)$} \\
\hline & $0.118^{*}$ & $(0.068)$ & 0.110 & $(0.069)$ & -0.056 & $(0.090)$ \\
\hline$\%$ emp. TBW & $0.102^{* *}$ & $(0.051)$ & 0.085 & $(0.052)$ & -0.068 & $(0.077)$ \\
\hline$\%$ emp. $\mathrm{MICT} * \%$ emp. TBW & & & & & $0.380^{* * *}$ & $(0.137)$ \\
\hline \% emp. working with PC & & & $0.231^{* *}$ & $(0.092)$ & $0.242^{* * *}$ & $(0.093)$ \\
\hline$\%$ emp. internet access & & & -0.025 & $(0.084)$ & -0.008 & $(0.084)$ \\
\hline competitiveness: above average & ref. & & ref. & & ref. & \\
\hline competitiveness: average & -0.004 & $(0.039)$ & -0.007 & $(0.039)$ & -0.010 & $(0.039)$ \\
\hline competitiveness: below average & -0.045 & $(0.109)$ & -0.037 & $(0.108)$ & -0.032 & $(0.110)$ \\
\hline Controls & Yes & & Yes & & Yes & \\
\hline Adjusted $R^{2}$ & 0.855 & & 0.856 & & 0.857 & \\
\hline Observations & 1045 & & 1045 & & 1045 & \\
\hline
\end{tabular}

Note: OLS estimations. This table replicates Table 2 and additionally controls for market concentration. All columns include controls for capital, labour, industry and regional dummies, general ICT-intensity and internet use, the skill and age profile of the workforce, the incidence of overtime, the firm's export share, the presence of a works council and a constant (not shown but available upon request). Standard errors in parentheses robust to heteroskedasticity. ${ }^{*} p<.10,{ }^{* *} p<.05,{ }^{* * *} p<.01$. 
Table A.9: IV Estimation - First Stage Regression

\begin{tabular}{lcccc}
\hline \hline & \multicolumn{2}{c}{$(1)$} & & $(2)$ \\
& $\%$ emp. mobile ICT & \% emp. MICT * \% emp. TBW \\
\hline average MICT (ind./size) & $0.517^{* * *}$ & $(0.143)$ & -0.112 & $(0.074)$ \\
average MICT (ind./size) * $\%$ emp. TBW & 0.063 & $(0.154)$ & $0.976^{* * *}$ & $(0.125)$ \\
years of smartphone use & $0.010^{* * *}$ & $(0.003)$ & -0.000 & $(0.001)$ \\
years of smartphone use * emp. TBW & 0.001 & $(0.006)$ & $0.010^{* *}$ & $(0.005)$ \\
\% emp. TBW & 0.048 & $(0.064)$ & 0.006 & $(0.056)$ \\
\% emp. working with PC & $-0.078^{*}$ & $(0.045)$ & -0.042 & $(0.028)$ \\
\% emp. internet access & $0.223^{* * *}$ & $(0.041)$ & $0.068^{* * *}$ & $(0.024)$ \\
ln(employees) & $-0.030^{* * *}$ & $(0.011)$ & $-0.019^{* * *}$ & $(0.006)$ \\
ln(investment) & $0.016^{* * *}$ & $(0.006)$ & $0.011^{* * *}$ & $(0.004)$ \\
\% high-skilled emp. & $0.308^{* * *}$ & $(0.068)$ & $0.090^{* *}$ & $(0.041)$ \\
\% medium-skilled emp. & 0.021 & $(0.051)$ & -0.020 & $(0.025)$ \\
\% emp. under 30 & -0.007 & $(0.053)$ & -0.010 & $(0.035)$ \\
works council & -0.029 & $(0.026)$ & 0.000 & $(0.014)$ \\
export share & -0.073 & $(0.061)$ & -0.020 & $(0.042)$ \\
\% emp. overtime & 0.005 & $(0.026)$ & 0.013 & $(0.017)$ \\
constant & -0.024 & $(0.078)$ & $0.087^{* *}$ & $(0.042)$ \\
Industry \& Regional Dummies & Yes & & Yes & \\
\hline Observations & 1001 & & 1001 & \\
\hline \hline
\end{tabular}

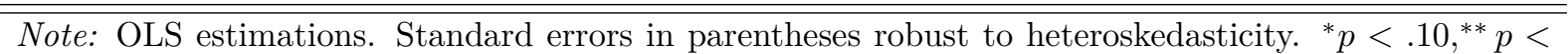
$.05,{ }^{* * *} p<.01$. 


\section{References}

Acemoglu, D., P. Aghion, C. Lelarge, J. Van Reenen, and F. Zilibotti (2007). "Technology, Information, and the Decentralization of the Firm". Quarterly Journal of Economics, 122(4): 1759-1799.

Akerlof, G. A. (1982). "Labor Contracts as Partial Gift Exchange". Quarterly Journal of Economics, 97(4): 543-569.

Alonso, R., W. Dessein, and N. Matouschek (2008). "When does Coordination Require Centralization?" American Economic Review, 98(1): 145-179.

Aral, S., E. Brynjolfsson, and L. Wu (2012). "Three-Way Complementarities: Performance Pay, HR Analytics and Information Technology". Management Science, 58(5): 913931.

Aral, S. and P. Weill (2007). "IT Assets, Organizational Capabilities, and Firm Performance: How Resource Allocations and Organizational Differences Explain Performance Variation". Organization Science, 18(5): 763-780.

Askenazy, P. and E. Caroli (2010). "Innovative Work Practices, Information Technologies, and Working Conditions: Evidence for France". Industrial Relations: A Journal of Economy and Society, 49(4): 544-565.

Athey, S. and S. Stern (1998). An Empirical Framework for Testing Theories About Complimentarity in Organizational Design. NBER Working Paper No. 6600.

Autor, D. H., F. Levy, and R. J. Murnane (2002). "Upstairs, Downstairs: Computers and Skills on two Floors of a Large Bank". Industrial and Labor Relations Review, 55(3): $432-447$.

Autor, D. H., F. Levy, and R. J. Murnane (2003). "The Skill Content of Recent Technological Change: An Empirical Exploration". Quarterly Journal of Economics, 118(4): $1279-1333$.

Avery, C. and D. Zabel (2001). The Flexible Workplace: A Sourcebook of Information and Research. Santa Barbara, CA: Greenwood Publishing Group.

Bartel, A., C. Ichniowski, and K. Shaw (2007). "How does Information Technology Affect Productivity? Plant-Level Comparisons of Product Innovation, Process Improvement, and Worker Skills". Quarterly Journal of Economics, 122(4): 1721-1758.

Beckmann, M. (2016). Self-managed Working Time and Firm Performance: Microeconometric Evidence. Mimeo. WWZ Working Paper.

Beckmann, M., T. Cornelissen, and M. Kräkel (2017). "Self-managed Working Time and Employee Effort: Theory and Evidence". Journal of Economic Behavior \&5 Organization, 133: 285-302.

Beckmann, M. and I. Hegedues (2011). Trust-Based Working Time and Organizational Performance: Evidence from German Establishment-Level Panel Data. WWZ Discussion Paper No. 2011/13.

Berg, P., E. Appelbaum, T. Bailey, and A. L. Kalleberg (2004). "Contesting Time: International Comparisons of Employee Control of Working Time". Industrial and Labor Relations Review, 57(3): 331-349.

Bertschek, I. (2012). "ICT, Internet and Worker Productivity". In: The New Palgrave Dictionary of Economics, Online Edition. Ed. by S. N. Durlauf and L. E. Blume. Vol. 6.

Bertschek, I. and U. Kaiser (2004). "Productivity Effects of Organizational Change: Microeconometric Evidence". Management Science, 50(3): 394-404. 
Bertschek, I. and T. Niebel (2013). Mobile and More Productive? Firm-Level Evidence on the Productivity Effects of Mobile Internet Use at the Early Stage of Diffusion. ZEW Discussion Paper No. 13-118 9, pp. 888-898.

Bertschek, I. and T. Niebel (2016). "Mobile and More Productive? Firm-Level Evidence on the Productivity Effects of Mobile Internet Use". Telecommunications Policy, 40(9): 888-898.

Bertschek, I., J. Ohnemus, and S. Viete (2017). "The ZEW ICT Survey 2002 to 2015: Measuring the Digital Transformation in German Firms". Jahrbücher für Nationalökonomie und Statistik. Available at: https://doi.org/10.1515/jbnst-2016-1005.

Biesebroeck, J. V. (2007). "Complementarities in Automobile Production". Journal of Applied Econometrics, 22(7): 1315-1345.

Black, S. E. and L. M. Lynch (2001). "How to Compete: The Impact of Workplace Practices and Information Technology on Productivity". Review of Economics and Statistics, 83(3): 434-445.

Black, S. E. and L. M. Lynch (2004). "What's Driving the new Economy? The Benefits of Workplace Innovation". Economic Journal, 114(493): F97-F116.

Bloom, N., L. Garicano, R. Sadun, and J. Van Reenen (2014). "The Distinct Effects of Information Technology and Communication Technology on Firm Organization". Management Science, 60(12): 2859-2885.

Bloom, N., J. Liang, J. Roberts, and Z. J. Ying (2015). "Does Working from Home Work? Evidence from a Chinese Experiment". Quarterly Journal of Economics, 130(1): 165218.

Bloom, N., R. Sadun, and J. Van Reenen (2012). "Americans do IT Better: US Multinationals and the Productivity Miracle". American Economic Review, 102(1): 167201.

Bloom, N. and J. Van Reenen (2011). "Human Resource Management and Productivity". In: Handbook of Labor Economics. Ed. by D. Card and O. Ashenfelter. Vol. 4. Oxford: Elsevier, pp. 1697-1767.

Bloom, N. and J. van Reenen (2007). "Measuring and Explaining Management Practices Across Firms and Countries". Quarterly Journal of Economics, 122(4): 1351-1408.

Boswell, W. R. and J. B. Olson-Buchanan (2007). "The Use of Communication Technologies After Hours: The Role of Work Attitudes and Work-Life Conflict". Journal of Management, 33(4): 592-610.

Bresnahan, T. F., E. Brynjolfsson, and L. M. Hitt (2002). "Information Technology, Workplace Organization, and the Demand for Skilled Labor: Firm-level Evidence". The Quarterly Journal of Economics, 117(1): 339-376.

Brynjolfsson, E. and L. M. Hitt (2000). "Beyond Computation: Information Technology, Organizational Transformation and Business Performance". Journal of Economic Perspectives, 14(4): 23-48.

Brynjolfsson, E. and L. M. Hitt (2003). "Computing Productivity: Firm-level evidence". Review of Economics and Statistics, 85(4): 793-808.

Brynjolfsson, E. and P. Milgrom (2013). "Complementarity in Organizations". In: Handbook of Organizational Economics. Ed. by R. Gibbons and J. Roberts. Princeton, NJ: Princeton University Press, pp. 11-55.

Cappelli, P. and D. Neumark (2001). "Do "High-Performance" Work Practices Improve Establishment-Level Outcomes?" Industrial and Labor Relations Review, 54(4): 737775 . 
Cardona, M., T. Kretschmer, and T. Strobel (2013). "ICT and Productivity: Conclusions From the Empirical Literature". Information Economics and Policy, 25(3): 109-125.

Caroli, E. and J. Van Reenen (2001). "Skill-biased Organizational Change? Evidence from a Panel of British and French Establishments". Quarterly Journal of Economics, 116(4): 1449-1492.

Centre for European Economic Research (ZEW) (2015). "Industrie 4.0: Digitale (R)Evolution der Wirtschaft". ZEW IKT-Report, Mannheim. Ed. by T. Niebel, J. Ohnemus, and S. Viete.

Council of Economic Advisors (2010). Work-Life Balance and the Economics of Workplace Flexibility. URL: http://www . whitehouse.gov/files/documents/\%20100331-ceaeconomics-workplace-flexibility.pdf.

Deci, E. and R. Ryan (1985). Intrinsic Motivation and Self-Determination in Human Behavior. Vol. 3. New York, NY: Springer US.

Draca, M., R. Sadun, and J. Van Reenen (2007). "Productivity and ICT: A Review of the Evidence". In: The Oxford Handbook of Information and Communication Technologies. Ed. by R. Mansell, C. Avgerou, and R. Silverstone. Oxford: Oxford University Press, pp. 100-147.

Entorf, H., M. Gollac, and F. Kramarz (1999). "New Technologies, Wages, and Worker Selection". Journal of Labor Economics, 17(3): 464-491.

Eurofound and the International Labour Office (2017). Working Anytime, Anywhere: The Effects on the World of Work. Luxembourg, Geneva: Publications Office of the European Union, Luxembourg, and the International Labour Office, Geneva.

Friedberg, L. (2003). "The Impact of Technological Change on Older Workers: Evidence from Data on Computer Use". Industrial and Labor Relations Review, 56(3): 511-529.

Garicano, L. and P. Heaton (2010). "Information Technology, Organization, and Productivity in the Public Sector: Evidence from Police Departments". Journal of Labor Economics, 28(1): 167-201.

Göbel, C. and T. Zwick (2012). "Age and Productivity: Sector Differences". De Economist, 160(1): 35-57.

Godart, O. N., H. Görg, and A. Hanley (2017). "Trust-based Work Time and Innovation: Evidence from Firm-Level Data”. Industrial and Labor Relations Review, 70(4): 894918.

Golden, A. G. and C. Geisler (2007). "Work-Life Boundary Management and the Personal Digital Assistant". Human Relations, 60(3): 519-551.

Goldin, C. (2014). "A Grand Gender Convergence: Its last Chapter". American Economic Review, 104(4): 1091-1119.

Hislop, D. and C. Axtell (2011). "Mobile Phones During Work and Non-work Time: A Case Study of Mobile, Non-managerial Workers". Information and Organization, 21(1): 41-56.

Hitt, L. M. and E. Brynjolfsson (1997). "Information Technology and Internal Firm Organization: An Exploratory Analysis". Journal of Management Information Systems, 14(2): 81-101.

Hitt, L. M. and P. Tambe (2016). "Health care information technology, work organization, and nursing home performance". Industrial and Labor Relations Review, 69(4): 834859.

Holmstrom, B. and P. Milgrom (1994). "The Firm as an Incentive System". American Economic Review: 972-991. 
Homans, G. C. (1958). "Social Behavior as Exchange". American Journal of Sociology, 63(6): 597-606.

Hottenrott, H., S. Rexhäuser, and R. Veugelers (2016). "Organisational Change and the Productivity Effects of Green Technology Adoption". Resource and Energy Economics, 43: $172-194$.

Ichniowski, C., T. A. Kochan, D. Levine, C. Olson, and G. Strauss (1996). "What Works at Work: Overview and Assessment". Industrial Relations: A Journal of Economy and Society, 35(3): 299-333.

Ichniowski, C. and K. Shaw (2003). "Beyond Incentive Pay: Insiders' Estimates of the Value of Complementary Human Resource Management Practices". Journal of Economic Perspectives, 17(1): 155-180.

Ichniowski, C., K. Shaw, and G. Prennushi (1997). "The Effects of Human Resource Management Practices on Productivity: A Study of Steel Finishing Lines". American Economic Review, 87(3): 291-313.

Jovanovic, B. and D. Stolyarov (2000). "Optimal Adoption of Complementary Technologies". American Economic Review, 90(1): 15-29.

Kelly, E. L., P. Moen, and E. Tranby (2011). "Changing workplaces to reduce workfamily conflict: Schedule control in a white-collar organization". American Sociological Review, 76(2): 265-290.

Kossek, E. E. and J. S. Michel (2010). "Flexible Work Schedules". In: Handbook of Industrial and Organizational Psychology: Building and Developing the Organization. Ed. by S. Zedeck. Vol. 1. NE, Washington: American Psychological Association, pp. 535-572.

Kretschmer, T. (2012). Information and Communication Technologies and Productivity Growth: A Survey of the Literature. OECD Digital Economy Paper No. 195.

Lazear, E. P. and M. Gibbs (2015). Personnel Economics in Practice. 3rd ed. Hoboken, NJ: Wiley.

Lileeva, A. and D. Trefler (2010). "Improved Access to Foreign Markets Raises Plant-Level Productivity... for some Plants". Quarterly Journal of Economics, 125(3): 1051-1099.

Litwin, A. S. (2011). "Technological Change at Work: The Impact of Employee Involvement on the Effectiveness of Health Information Technology". ILR Review, 64(5): 863888.

Mazmanian, M., W. J. Orlikowski, and J. Yates (2013). "The Autonomy Paradox: The Implications of Mobile Email Devices for Knowledge Professionals". Organization Science, 24(5): 1337-1357.

Meijman, T. F. and G. Mulder (1998). "Psychological Aspects of Workload". In: Handbook of Work and Organizational Psychology. Ed. by P. J. D. Drenth, H. Thierry, and C. J. de Wolff. Vol. 2. New York, NY: Hove, Psychology Press, pp. 5-33.

Milgrom, P. and J. Roberts (1990). "The Economics of Modern Manufacturing: Technology, Strategy, and Organization". American Economic Review, 80(3): 511-28.

Moen, P., E. L. Kelly, E. Tranby, and Q. Huang (2011). "Changing Work, Changing Health: Can Real Work-time Flexibility Promote Health Behaviors and Well-being?" Journal of Health and Social Behavior, 52(4): 404-429.

Pfeifer, C. (2016). "Intra-firm Wage Compression and Cost Coverage of Training: Evidence from Linked Employer-Employee Data". ILR Review, 69(2): 435-454.

Pierce, J. L. and J. W. Newstrom (1980). "Toward a Conceptual Clarification of Employee Responses to Flexible Working Hours: A work Adjustment Approach". Journal of Management, 6(2): 117-134. 
Prendergast, C. (2002). "The Tenuous Trade-off Between Risk and Incentives". Journal of political Economy, 110(5): 1071-1102.

Promberger, M. (2001). "Industriebeschäftigte in hochflexiblen Arbeitszeitarrangements: Nutzbarkeit und Nutzung zeitlicher Gestaltungsspielräume". WSI Mitteilungen, 54: 626-631.

Rasel, F. (2016). "Combining Information Technology and Decentralized Workplace Organization: SMEs versus Larger Firms". International Journal of the Economics of Business, 23(2): 199-241.

Raymond, W., J. Mairesse, P. Mohnen, and F. Palm (2015). "Dynamic Models of R \& D, Innovation and Productivity: Panel Data Evidence for Dutch and French Manufacturing". European Economic Review, 78: 285-306.

Seifert, H. (1993). "Ausmaß und Effekte der Arbeitszeitverkürzung". In: Zwischenbilanz der Arbeitzeitverkuerzung. Ed. by P. Hampe. Hase \& Koehler, pp. 11-28.

Shepard, E. M., T. J. Clifton, and D. Kruse (1996). "Flexible Work Hours and Productivity: Some Evidence from the Pharmaceutical Industry". Industrial Relations, 35(1): $123-139$.

Singe, I. and R. Croucher (2003). "The Management of Trust-Based Working Time in Germany". Personnel Review, 32(4): 492-509.

Sonnentag, S. (2001). "Work, Recovery Activities, and Individual Well-being: A Diary Study". Journal of Occupational Health Psychology, 6(3): 196.

Syverson, C. (2011). "What Determines Productivity?" Journal of Economic Literature, 49(2): 326-365.

Tambe, P., L. M. Hitt, and E. Brynjolfsson (2012). "The Extroverted Firm: How External Information Practices Affect Innovation and Productivity". Management Science, 58(5): 843-859.

Wingen, S. (2004). Vertrauensarbeitszeit: Neue Entwicklung gesellschaftlicher Arbeitszeitstrukturen. Bremerhaven: Wirtschaftsverlag NW, Verlag für neue Wissenschaft. 